Prepared in cooperation with the U.S. Army Corps of Engineers, San Francisco District

\title{
Summary of Suspended-Sediment Concentration Data, San Francisco Bay, California, Water Year 2009
}

Data Series 744 



\section{Summary of Suspended-Sediment Concentration Data, San Francisco Bay, California, Water Year 2009}

By Paul A. Buchanan and Tara L. Morgan

Prepared in cooperation with the

U.S. Army Corps of Engineers, San Francisco District

Data Series 744

U.S. Department of the Interior

U.S. Geological Survey 


\title{
U.S. Department of the Interior \\ KEN SALAZAR, Secretary \\ U.S. Geological Survey \\ Marcia K. McNutt, Director
}

\author{
U.S. Geological Survey, Reston, Virginia: 2012
}

For more information on the USGS - the Federal source for science about the Earth, its natural and living resources, natural hazards, and the environment, visit http://www.usgs.gov or call 1-888-ASK-USGS.

For an overview of USGS information products, including maps, imagery, and publications, visit http://www.usgs.gov/pubprod

To order this and other USGS information products, visit http://store.usgs.gov

Any use of trade, firm, or product names is for descriptive purposes only and does not imply endorsement by the U.S. Government.

Although this information product, for the most part, is in the public domain, it also may contain copyrighted materials as noted in the text. Permission to reproduce copyrighted items must be secured from the copyright owner.

Suggested citation:

Buchanan, P.A., and Morgan, T.L., 2012, Summary of suspended-sediment concentration data, San Francisco Bay, California, water year 2009: U.S. Geological Survey Data Series 744, 26 p. 


\section{Acknowledgments}

The project was done in cooperation with the U.S. Army Corps of Engineers, San Francisco District, as part of the San Francisco Estuary Regional Monitoring Program for Trace Substances. The authors gratefully acknowledge the U.S. Coast Guard (USCG), the National Park Service, California Department of Transportation, and California Department of Water Resources (DWR) for their permission and assistance in establishing the monitoring sites used in this study.

The authors also wish to acknowledge Amber Forest for her assistance with sample collection and maintenance of the data-collection network. 


\section{Contents}

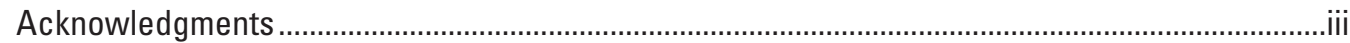

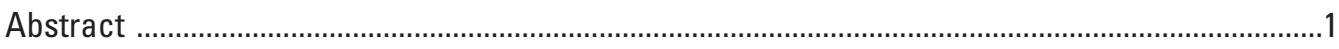

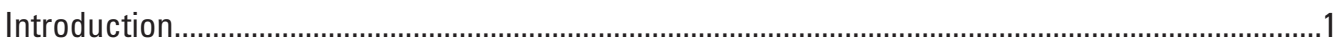

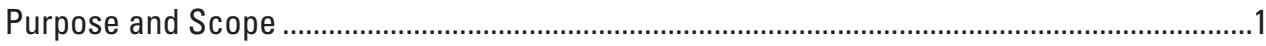

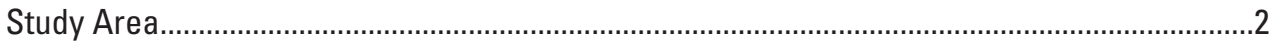

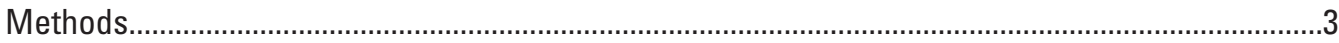

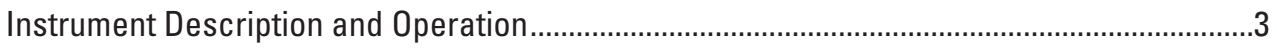

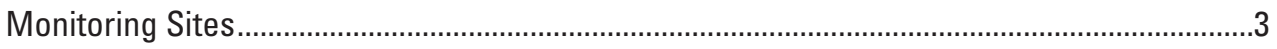

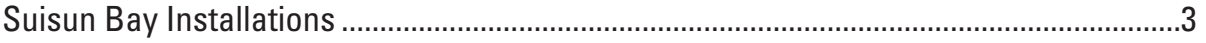

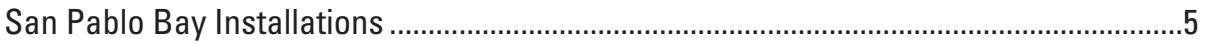

Central San Francisco Bay Installations............................................................................5

South San Francisco Bay Installations .......................................................................... 5

Water-Sample Collection..................................................................................................

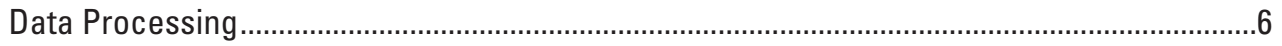

Sensor Calibration and Suspended-Sediment Concentration Data................................................

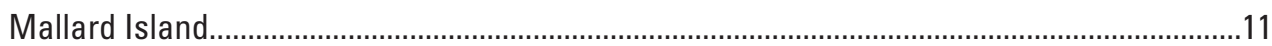

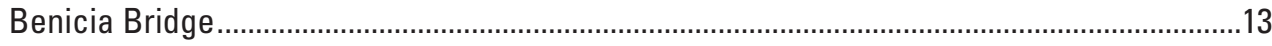

Hamilton Disposal Site ..................................................................................................... 16

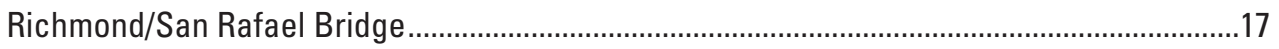

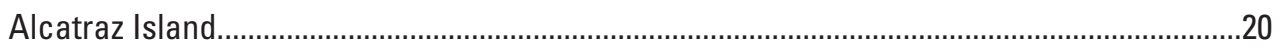

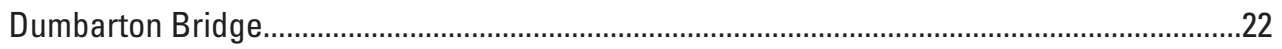

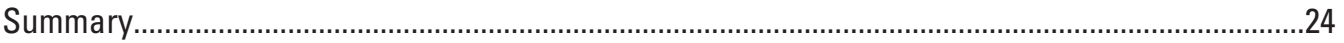

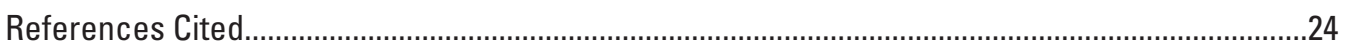




\section{Figures}

1. Figure showing San Francisco Bay study area, California ................................................

2. Schematic showing typical monitoring installation, San Francisco Bay study .................4

3. Illustration showing typical monitoring installation, Hamilton Disposal site, San Pablo Bay.

4. Photo showing scientist collecting a water sample by using a horizontally-positioned Van Dorn-style sampler with bridge board..

5. Graphs showing example of optical sensor data, near-bottom sensor, Richmond/San Rafael Bridge, Central San Francisco Bay, California, water year 2009

6. Graphs showing calibration of optical sensors at Mallard Island, Suisun Bay, California, water year 2009.

7. Graphs showing time series of suspended-sediment concentrations calculated from sensor readings at Mallard Island, Suisun Bay, California, water year 2009..........12

8. Graphs showing calibration of optical sensors at Benicia Bridge, Suisun Bay, California, water year 2009.

9. Graphs showing time series of suspended-sediment concentrations calculated from sensor readings at Benicia Bridge, Suisun Bay, California, water year 2009.........15

10. Graph showing calibration of near-bottom optical sensors at Hamilton Disposal Site, San Pablo Bay, California, water year 2009.

11. Graph showing time series of near-bottom suspended-sediment concentrations calculated from sensor readings at Hamilton Disposal Site, San Pablo Bay, California, water year 2009.

12. Graphs showing calibration of optical sensors at Richmond/San Rafael Bridge, Central San Francisco Bay, California, water year 2009.

13. Graphs showing time series of suspended-sediment concentrations calculated from sensor readings at Richmond/San Rafael Bridge, Central San Francisco Bay, California, water year 2009.

14. Graph showing calibration of mid-depth optical sensors at Alcatraz Island, Central San Francisco Bay, California, water year 2009.

15. Graph showing time series of mid-depth suspended-sediment concentrations calculated from sensor readings at Alcatraz Island, Central San Francisco Bay, California, water year 2009.

16. Graphs showing calibration of optical sensors at Dumbarton Bridge, South San Francisco Bay, California, water year 2009

17. Graphs showing time series of suspended-sediment concentrations calculated from sensor readings at Dumbarton Bridge, South San Francisco Bay, California, water year 2009 


\section{Tables}

1. Optical sensor depths (in feet) below mean lower low water (MLLW), Suisun Bay, San Pablo Bay, and Central and South San Francisco Bays, California, water year 2009

2. Statistical summary of calculated suspended-sediment concentration data and usable percentage of a complete year of valid data (96 data points per day x 365 days) collected by using optical sensors, Suisun Bay, San Pablo Bay, and Central and South San Francisco Bays, California, water year 2009...

3. Summary of suspended-sediment concentration calibration statistics, Suisun Bay, San Pablo Bay, and Central and South San Francisco Bays, California, water year 2009 


\section{Conversion Factors}

Inch/Pound to SI

\begin{tabular}{|c|c|c|}
\hline Multiply & By & To obtain \\
\hline \multicolumn{3}{|c|}{ Length } \\
\hline inch (in) & 25.4 & millimeter $(\mathrm{mm})$ \\
\hline foot $(\mathrm{ft})$ & 0.3048 & meter $(\mathrm{m})$ \\
\hline foot per second (ft/s) & 0.3048 & meter per second $(\mathrm{m} / \mathrm{s})$ \\
\hline
\end{tabular}

Temperature in degrees Celsius $\left({ }^{\circ} \mathrm{C}\right)$ may be converted to degrees Fahrenheit $\left({ }^{\circ} \mathrm{F}\right)$ as follows:

$$
{ }^{\circ} \mathrm{F}=\left(1.8 \times{ }^{\circ} \mathrm{C}\right)+32
$$

Vertical coordinate information is referenced to the North American Vertical Datum of 1988 (NAVD 88).

Horizontal coordinate information is referenced to the North American Datum of 1927 (NAD 27).

Mean lower low water (MLLW): The average of the lower low water height above the bottom, in feet, of each tidal day observed during the National Tidal Datum Epoch. The National Tidal Datum Epoch is the specific 19-year period (1960-78 for values given in this report) adopted by the National Ocean Service as the official time segment during which tide observations are taken and reduced to obtain mean values.

\section{Abbreviations}

$\begin{array}{ll}\text { ADAPS } & \text { USGS Automated Data-Processing System } \\ \text { DWR } & \text { California Department of Water Resources } \\ \text { FNU } & \text { formazin nephelometric units } \\ \text { FTS } & \text { Forest Technology Systems } \\ \text { mg/L } & \text { milligram per liter } \\ \text { mV } & \text { millivolt } \\ \text { NTU } & \text { nephelometric turbidity unit } \\ \text { OLS } & \text { ordinary least squares (regression) } \\ P I & \text { nonparametric prediction interval } \\ \text { PVC } & \text { polyvinyl chloride } \\ \text { RMS } & \text { root-mean-squared (error) } \\ \text { SSC } & \text { suspended-sediment concentration } \\ \text { USCG } & \text { U.S. Coast Guard } \\ \text { USGS } & \text { U.S. Geological Survey } \\ \text { WY } & \text { water year (October 1-September 30) }\end{array}$


viii

This page intentionally left blank. 


\title{
Summary of Suspended-Sediment Concentration Data, San Francisco Bay, California, Water Year 2009
}

\author{
By Paul A. Buchanan and Tara L. Morgan
}

\begin{abstract}
Suspended-sediment concentration data were collected by the U.S. Geological Survey in San Francisco Bay during water year 2009 (October 1, 2008-September 30, 2009). Optical sensors and water samples were used to monitor suspended-sediment concentration at two sites in Suisun Bay, one site in San Pablo Bay, two sites in Central San Francisco Bay, and one site in South San Francisco Bay. Sensors were positioned at two depths at most sites to help define the vertical variability of suspended sediments. Water samples were collected periodically and analyzed for concentrations of suspended sediment. The results of the analyses were used to calibrate the output of the optical sensors so that a record of suspended-sediment concentrations could be derived. This report presents the data-collection methods used and summarizes, in graphs, the suspended-sediment concentration data collected from October 2008 through September 2009. Calibration curves and plots of the processed data for each sensor also are presented.
\end{abstract}

\section{Introduction}

Sediments are an important component of the San Francisco Bay estuarine system. Bottom sediments provide habitat for benthic organisms and are a reservoir for nutrients that contribute to estuarine productivity (Hammond and others, 1985). Potentially toxic substances, such as metals and pesticides, can adsorb to sediment particles (Kuwabara and others, 1989; Domagalski and Kuivila, 1993; Flegal and others, 1996). Benthic organisms can then ingest these substances and introduce them into the food web (Luoma and others, 1985; Brown and Luoma, 1995; Luoma, 1996). The mobilization, resuspension, and deposition of suspended sediments are important factors in determining the transport and fate of sediment-associated contaminants. Large tidal-induced current velocities and wind waves in shallow water are capable of resuspending bottom sediments (Powell and others, 1989; Schoellhamer, 1996). Suspended sediments limit the penetration of light into San Francisco Bay and, thus, affect photosynthesis and primary phytosynthetic carbon production (Cloern, 1987, 1996; Cole and Cloern, 1987). Sediments are also deposited in ports and shipping channels, which then require dredging to remain navigable (U.S. Environmental Protection Agency, 1992).

In Suisun Bay, the maximum suspended-sediment concentration (SSC) typically marks the position of the turbidity maximum - a crucial ecological zone where suspended sediments, nutrients, phytoplankton, zooplankton, larvae, and juvenile fish accumulate (Peterson and others, 1975; Arthur and Ball, 1979; Kimmerer, 1992; Jassby and Powell, 1994; Schoellhamer and Burau, 1998; Schoellhamer, 2001). The U.S. Geological Survey (USGS), in cooperation with the U.S. Army Corps of Engineers, San Francisco District, has been studying the factors that affect SSC in San Francisco Bay since water year (WY) 1992.

\section{Purpose and Scope}

This report summarizes SSC data collected by the USGS in San Francisco Bay during WY 2009 and is the latest in a series of reports that present the data collected beginning in WY 1992 (Buchanan and Schoellhamer, 1995, 1996, 1998, 1999; Buchanan and others, 1996; Buchanan and Ruhl, 2000, 2001; Buchanan and Ganju, 2002, 2003, 2004, 2005; Buchanan and Lionberger, 2006, 2007, 2009; and Buchanan and Morgan, 2010, 2011). Collection of SSC data in San Francisco Bay required development of monitoring methods and calibration techniques, which are presented in this report. SSC was monitored at two sites in Suisun Bay, one site in San Pablo Bay, two sites in Central San Francisco Bay, and one site in South San Francisco Bay. SSC data from WY 1992 through WY 2009 were used to help determine the factors that affect SSC in San Francisco Bay (U.S. Geological Survey, variously dated, at URL http://ca.water.usgs.gov/user_projects/sfbay/publications_group.htm). Numerical SSC data are available from the U.S. Geological Survey (variously dated, at URL http://sfbay.wr.usgs.gov/sediment/ cont_monitoring/index.html). 


\section{Study Area}

San Francisco Bay (fig. 1) comprises several major subembayments: Suisun Bay, San Pablo Bay, Central San Francisco Bay (Central Bay), and South San Francisco Bay (South Bay). In San Francisco Bay, tides are semidiurnal (two high and two low tides per day) and have a range of about $5.5 \mathrm{feet}$ (ft) in Suisun Bay, $6.5 \mathrm{ft}$ at the Golden Gate and Central Bay, and about $10 \mathrm{ft}$ in South Bay. The tides also follow a 14 and 3/4-day spring-neap cycle. Typical tidal currents range from 0.6 foot per second (ft/s) in shallow water to more than $3 \mathrm{ft} / \mathrm{s}$ in deep channels (Cheng and Gartner, 1984; Smith, 1987). Typically, the strongest winds are sea breezes that blow onshore during summer afternoons. Most precipitation occurs from late autumn to early spring. Freshwater discharge into San Francisco Bay is greatest in the spring as a result of runoff from snowmelt flowing into the Sacramento-San Joaquin River Delta. About 90 percent of the discharge into the Bay is from the Sacramento-San Joaquin River Delta (the Delta), which drains the Central Valley of California (Smith, 1987).

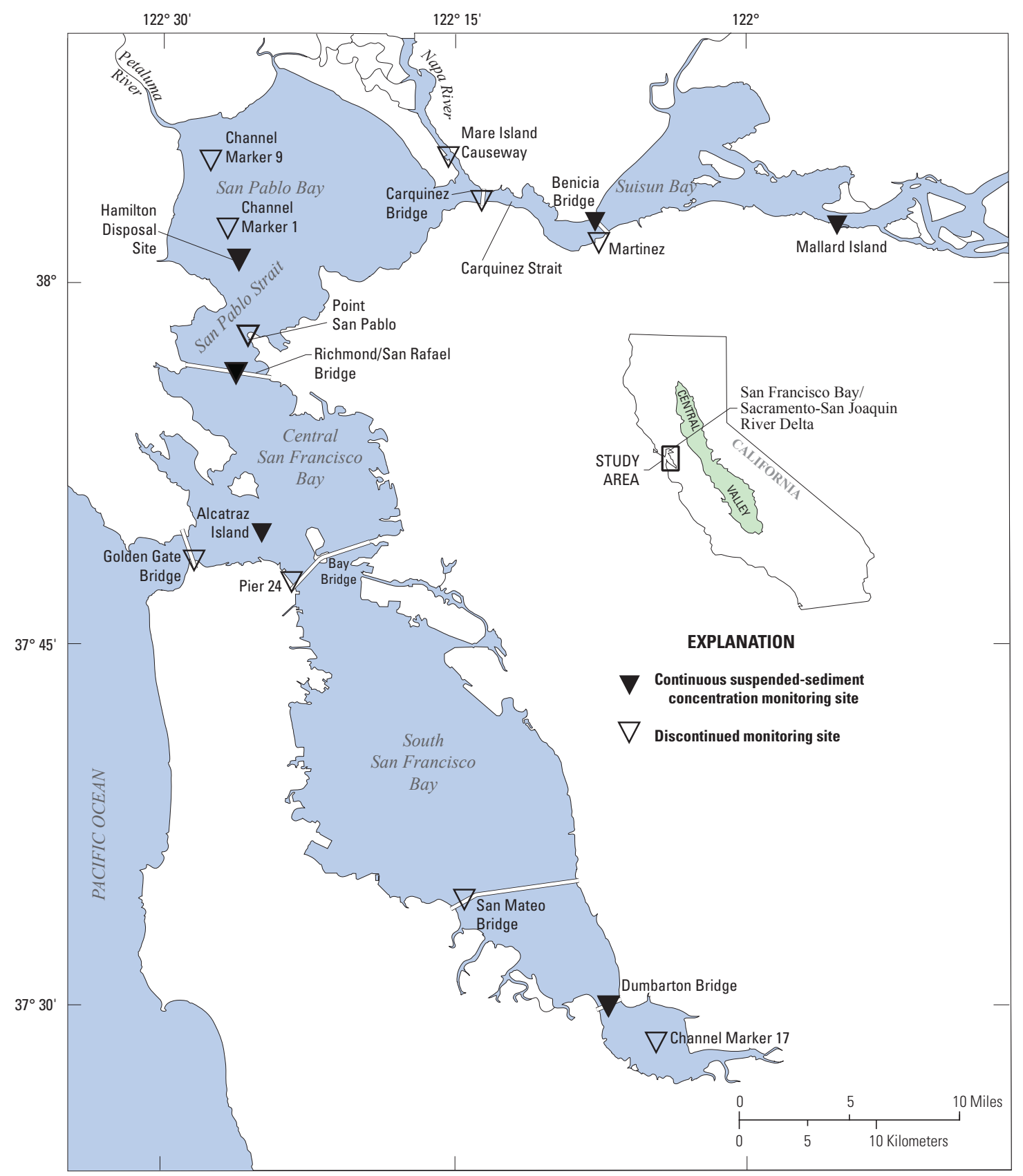

Figure 1. San Francisco Bay study area, California. 
Typically, discharge from the Delta contains about 44 percent of the fluvial sediments that enter the Bay (Lewicki and McKee, 2009), although this percentage varies from year to year. Local tributaries, defined as tributaries that enter the Bay seaward of Mallard Island, supply 56 percent of the fluvial sediments that enter the Bay. During wet winters, turbid plumes of water from the Delta have extended into South Bay (Carlson and McCulloch, 1974). The bottom sediments in South Bay and in the shallow water areas (about $12 \mathrm{ft}$ or less) of Central, San Pablo, and Suisun Bays are composed mostly of silts and clays. Silts and sands are present in the deeper parts of Central, San Pablo, and Suisun Bays and in Carquinez Strait (Conomos and Peterson, 1977).

\section{Methods}

\section{Instrument Description and Operation}

Two types of optical sensors were used to monitor SSC during WY 2009. The first type of sensor, the DTS-12 manufactured by Forest Technology Systems (FTS), is self-cleaning and measures the intensity of light scattered at 90 degrees between a laser diode (780 nanometer wavelength) and a high-sensitivity silicon photodiode detector. The output, in formazin nephelometric units (FNU), is converted to millivolts $(\mathrm{mV})$ when recorded on a separate data logger. The second type of sensor, model 6136 manufactured by YSI, Inc., also measures the intensity of light scattered at 90 degrees between a light-emitting diode ( $860 \pm 30$ nanometer wavelength) and a high-sensitivity photodiode detector, and the output (FNU) is processed by internal software. In previous reports, the output of the DTS-12 and the YSI, Inc., sensors was reported as nephelometric turbidity units (NTU). The USGS has created new reporting units for turbidity that are based on the instrument design (U.S. Geological Survey, 2004). The design of both the DTS-12 and the YSI, Inc., instruments specifies the use of FNU as the reporting unit. The YSI, Inc., instruments (sondes) are self-contained and include a power source (AA-sized batteries), data logger, and the capability of supporting additional sensors. The YSI, Inc., and FTS data loggers collect instantaneous values every 15 minutes. Power to the data logger used with the DTS-12 sensor was supplied by 12-volt batteries.

Optical sensors were positioned in the water column by using polyvinyl chloride (PVC) pipe carriages coated with an antifoulant paint to impede biological growth. Carriages were designed to align with the direction of flow and to ride along a stainless steel suspension line attached to an anchor weight, which allowed sensors to be easily raised and lowered for servicing (fig. 2). The plane of the optical window maintained a position parallel to the direction of flow as the carriage aligned itself with the changing direction of flow. Optical sensor depths in the water column are listed in table 1.

Biological growth (fouling) interferes with the collection of accurate optical-sensor data. Self-cleaning optical sensors were used at all sites (cleaning cycle performed hourly). Fouling was generally greatest on the sensor closest to the water surface. Biological growth on the cleaning mechanism or the sensor body would begin to obscure the sensor optics and affect sensor output 5 days to several weeks after servicing a monitoring station, depending on the level of biological activity in the bay. Because of the difficulty in servicing some of the monitoring stations, sensors were cleaned manually every 3-5 (usually 3) weeks.

Generally, fouling was greatest during spring and summer.

Sensor performance was monitored by using known standards to identify output drift or sensor malfunction. On-site checks of sensor accuracy were performed by using turbidity solutions prepared from a 4,000-NTU formazin standard. Formazin is an aqueous suspension of an insoluble polymer and is the primary turbidity standard (Greenberg and others, 1992). The turbidity solutions were prepared by diluting a 4,000-NTU stock standard with de-ionized water in a clean, sealable container. Prepared solutions ranged from 0 to 200 NTU, which defined the expected range of turbidity values in WY 2009. Prepared solutions were checked with a Hach Drel 2000 Spectrophotometer for accuracy and were acceptable within 5 percent of measured value, as specified by Wagner and others (2006). At the field site, the cleaned sensors were immersed in the solution, and the output was recorded on the station log.

\section{Monitoring Sites}

\section{Suisun Bay Installations}

SSC data were collected in Suisun Bay at Mallard Island and at Benicia Bridge (fig. 1, table 1). Optical sensors were installed at the California Department of Water Resources (DWR) Mallard Island Compliance Monitoring Station on February 8, 1994, and were positioned to coincide with DWR near-surface and near-bottom electrical conductance and temperature sensors. DWR replaced the near-bottom sensors, near-surface pump intake, and associated flow-through water-quality monitor with YSI, Inc., monitors on April 16, 2008. The DWR near-surface YSI, Inc., monitor was attached to a float that positioned the monitor about $3 \mathrm{ft}$ below the surface. The near-surface optical sensor was attached to a separate float and positioned at the same depth as the DWR near-surface monitor. 


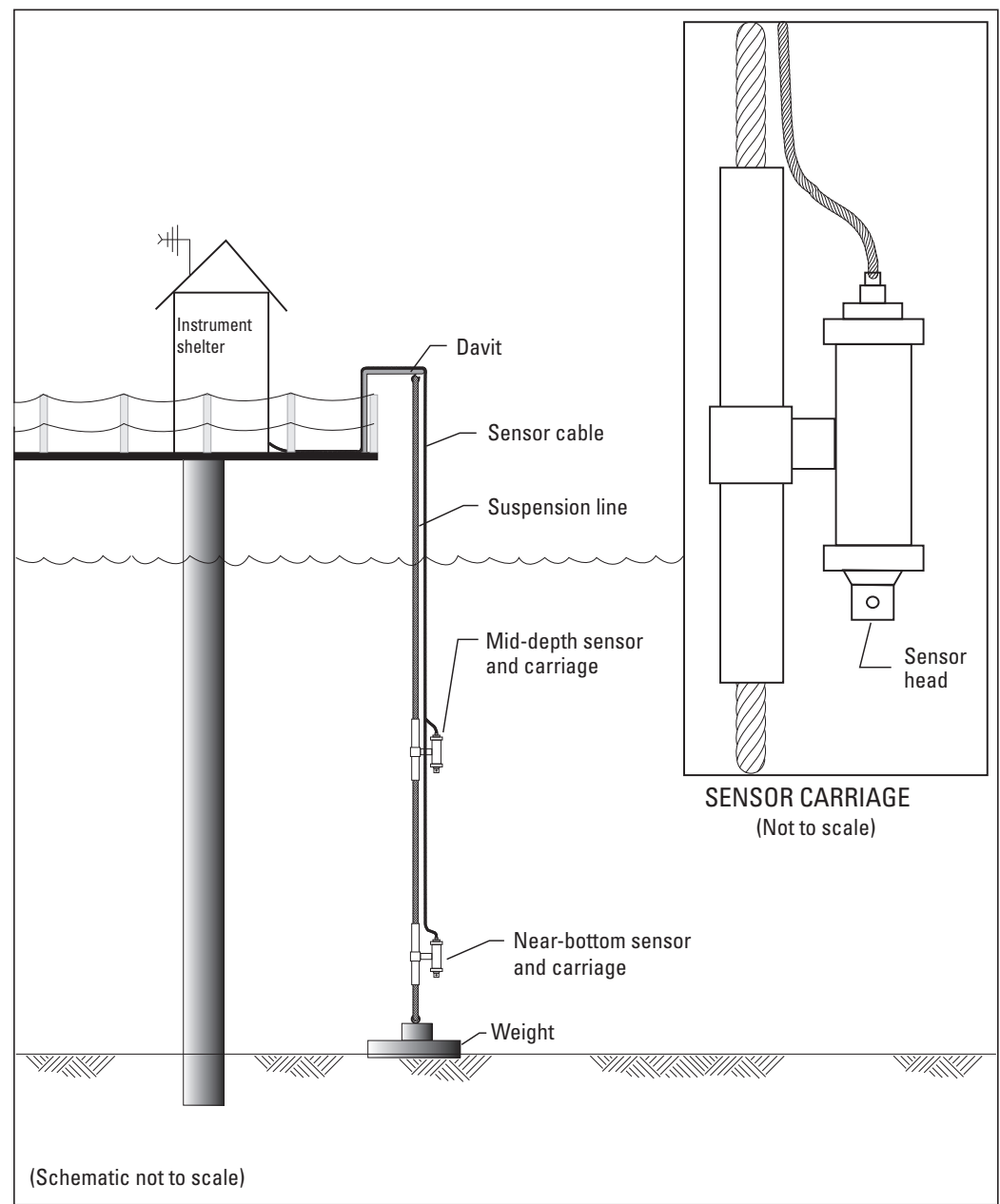

Figure 2. Typical monitoring installation, San Francisco Bay study.

Table 1. Optical sensor depths (in feet) below mean lower low water (MLLW), Suisun Bay, San Pablo Bay, and Central and South San Francisco Bays, California, water year 2009.

[Mean lower low water: The average of the lower low water height above the bottom, in feet, of each tidal day observed during the National Tidal Datum Epoch. The National Tidal Datum Epoch is the specific 19-year period (1960-78 for values given in this report) adopted by the National Ocean Service as the official time segment during which tide observations are taken and reduced to obtain mean values. Abbreviations: ${ }^{\circ}$, degrees; ', minutes; ’, seconds; -, not applicable]

\begin{tabular}{|c|c|c|c|c|c|c|}
\hline Site & Station number & Latitude & Longitude & Sensor depth & $\begin{array}{l}\text { Depth } \\
\text { below } \\
\text { MLLW' }\end{array}$ & $\begin{array}{l}\text { Water depth } \\
\text { at MLLW }\end{array}$ \\
\hline Mallard Island & 11185185 & $38^{\circ} 02^{\prime} 34^{\prime \prime}$ & $121^{\circ} 55^{\prime} 09^{\prime \prime}$ & Near-surface & 3.3 & 25 \\
\hline Mallard Island & 11185185 & $38^{\circ} 02^{\prime} 34^{\prime \prime}$ & $121^{\circ} 55^{\prime} 09^{\prime \prime}$ & Near-bottom & 20 & - \\
\hline Benicia Bridge & 11455780 & $38^{\circ} 02^{\prime} 42^{\prime \prime}$ & $122^{\circ} 07^{\prime} 32^{\prime \prime}$ & Near-surface & 9 & 80 \\
\hline Benicia Bridge & 11455780 & $38^{\circ} 02^{\prime} 42^{\prime \prime}$ & $122^{\circ} 07^{\prime} 32^{\prime \prime}$ & Near-bottom & 61 & - \\
\hline Hamilton Disposal Site & 380109122250401 & $38^{\circ} 01^{\prime} 09^{\prime \prime}$ & $122^{\circ} 25^{\prime} 04^{\prime \prime}$ & Mid-depth & 10 & 16 \\
\hline Richmond/San Rafael Bridge & 375607122264701 & $37^{\circ} 56^{\prime} 07^{\prime \prime}$ & $122^{\circ} 26^{\prime} 47^{\prime \prime}$ & Mid-depth & 15 & 45 \\
\hline Richmond/San Rafael Bridge & 375607122264701 & $37^{\circ} 56^{\prime} 07^{\prime \prime}$ & $122^{\circ} 26^{\prime} 47^{\prime \prime}$ & Near-bottom & 40 & - \\
\hline Alcatraz Island & 374938122251801 & $37^{\circ} 49^{\prime} 38^{\prime \prime}$ & $122^{\circ} 25^{\prime} 18^{\prime \prime}$ & Mid-depth & 6 & 16 \\
\hline Dumbarton Bridge & 373015122071000 & $37^{\circ} 30^{\prime} 15^{\prime \prime}$ & $122^{\circ} 07^{\prime} 10^{\prime \prime}$ & Mid-depth & 20 & 45 \\
\hline Dumbarton Bridge & 373015122071000 & $37^{\circ} 30^{\prime} 15^{\prime \prime}$ & $122^{\circ} 07^{\prime} 10^{\prime \prime}$ & Near-bottom & 41 & - \\
\hline
\end{tabular}

'Depth below water surface. 
Optical sensors were installed at Pier 7 on the Benicia Bridge on March 15, 1996. The Benicia Bridge station was shut down on August 7, 1998, for seismic retrofitting of the bridge and was reestablished on May 1, 2001, equipped with sondes having optical, conductance, and temperature sensors. A monitoring station at the Martinez Marina fishing pier was discontinued in WY 1996 because data from the Benicia Bridge site were considered more representative of SSC in the Carquinez Strait area of Suisun Bay (Buchanan and Schoellhamer, 1998).

\section{San Pablo Bay Installations}

SSC data were collected in San Pablo Bay at Hamilton Disposal Site (fig. 1, table 1). A sonde with optical, conductance, and temperature sensors was deployed by attaching to a stainless-steel cable moored with a subsurface buoy and lead weight (fig. 3) on November 9, 2005. The Hamilton site was discontinued on November 16, 2006, but reestablished on July 24, 2008. The sonde was co-located with an upward-looking acoustic Doppler current profiler used to collect velocity and waves data (fig. 3). A monitoring station at U.S. Coast Guard (USCG) Channel Marker 9 was discontinued on October 7, 2003. A monitoring station at USCG Channel Marker 1 was discontinued on September 28, 2005. A monitoring station at Napa River at Mare Island Causeway was discontinued on October 11, 2005. SSC monitoring was discontinued at Carquinez Bridge on October 19, 2005, although specific conductance and water temperature were monitored at this site in WY 2009. A monitoring station at Point San Pablo was discontinued on August 1, 2006.

\section{Central San Francisco Bay Installations}

SSC data were collected in Central San Francisco Bay at Alcatraz Island and at Richmond/San Rafael Bridge (fig. 1, table 1). A sonde with optical turbidity, conductance, and temperature sensors was installed on the northeast side of Alcatraz Island on November 6, 2003. Sondes with optical, conductance, and temperature sensors were installed on the Richmond/ San Rafael Bridge pier west of the main channel on October 18, 2006. A monitoring station at the south tower of the Golden Gate Bridge was operational during WY 1996 and WY 1997. A monitoring station at San Francisco Bay at Pier 24 was discontinued on January 3, 2002.

\section{South San Francisco Bay Installations}

SSC data were collected in South San Francisco Bay at Dumbarton Bridge (fig. 1, table 1). Optical sensors were installed at Pier 23 on the Dumbarton Bridge on the west side of the ship channel on October 21, 1992. SSC monitoring was discontinued at San Mateo Bridge on October 19, 2005, although specific conductance and water temperature were monitored at this site in WY 2009. A monitoring station at USCG Channel Marker 17 was discontinued on October 26, 2005.

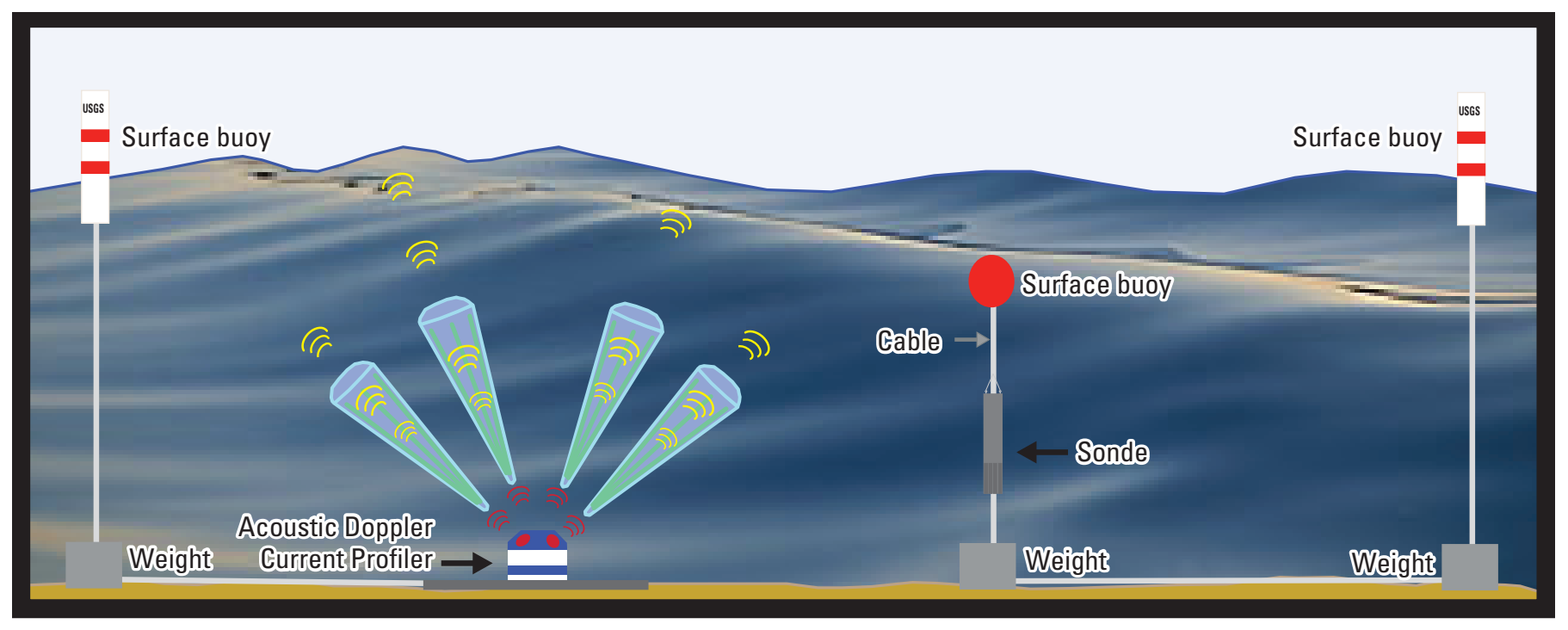

Figure 3. Typical monitoring installation, Hamilton Disposal site, San Pablo Bay. 


\section{Water-Sample Collection}

Water samples used to calibrate the output of the optical sensors to SSC were collected by using a horizontally positioned Van Dorn-style sampler, usually after the sensors were cleaned (fig.4). In previous WY's, samples were collected before the sensors were cleaned; however, the time-series data collected before cleaning was often unusable as a result of fouling, and the calibration points from the water samples were discarded. The Van Dorn-style sampler is a plastic tube with rubber stoppers at each end that snap shut when triggered by a small weight dropped down a suspension cable. The Van Dorn-style sampler was lowered to the depth of the sensor by a reel and crane assembly, then triggered while the sensor was collecting data. After collection, the water sample was marked for identification and placed in a clean, 1-liter plastic bottle for transport. The SSC of water samples collected with a Van Dorn-style sampler and a P-72 point sampler, used until WY 1994, were virtually identical (Buchanan and others, 1996).

SSC samples were analyzed at the USGS Sediment Laboratory in Marina, California. Suspended sediment includes all particles in the sample that do not pass through a 0.45 -micrometer membrane filter. The analytical method to quantify concentrations of suspended solid-phase material was used consistently from 1992 through the present study; however, the nomenclature used to describe sediment data was changed. Suspended-sediment concentrations were referred to as suspended-solids concentrations in previous reports (Buchanan and Schoellhamer, 1995, 1996, 1998, 1999; Buchanan and others, 1996; Buchanan and Ruhl, 2000, 2001), but because the total water-sediment mass and all sediment were measured in the analysis, these data are more appropriately referred to as SSC (Gray and others, 2000). Water samples collected for this study were analyzed for SSC, in milligrams per liter $(\mathrm{mg} / \mathrm{L})$, by filtering samples through a pre-weighed, tared, 0.45 -micrometer membrane filter. The filtrate was rinsed with de-ionized water to remove salts, and the insoluble material and filter were dried at 103 degrees Celsius, then weighed (Fishman and Friedman, 1989).

\section{Data Processing}

Data loggers recorded the optical-sensor output at 15-minute intervals (96 data points per day). Recorded data were downloaded from the data loggers onto either a storage module or laptop computer during site visits. Raw data from the storage modules or laptop computer were loaded into the USGS Automated Data-Processing System (ADAPS) and stored with appropriate data descriptors for electrical output and turbidity.

The time-series data were retrieved from ADAPS and processed to remove invalid data. Invalid data included rapidly increasing voltage outputs and unusually high-voltage outputs of short duration (spikes). As biological growth accumulated on the optical sensors, the voltage output of the sensors increased. An example time-series of raw and processed optical sensor data is presented in figure 5. After sensors were cleaned, sensor output immediately decreased (see fig. 5A). Efforts to correct for biofouling proved to be unsuccessful because the signal often was highly variable. Thus, data affected by biofouling were often unusable and were removed from the record (fig. $5 B$ ). Identifying the point at which fouling begins to affect optical sensor data is somewhat subjective. Indicators, such as an elevated baseline, an increasingly variable voltage signal, and comparisons with the output from other nearby sensors, were used to help define the point at which fouling began. Spikes in the data, which are anomalously high-voltage outputs probably caused by debris temporarily wrapped around the sensor or by large marine organisms (fish or crabs) on or near the sensor, were also removed from the raw data (fig. $5 B$ ). Sometimes, incomplete cleaning of a sensor (usually caused by a worn-out wiper pad) would cause a small, constant change in sensor output that could be corrected by applying a shift to the record based on water-sample data that had been collected for calibration of the sensors.

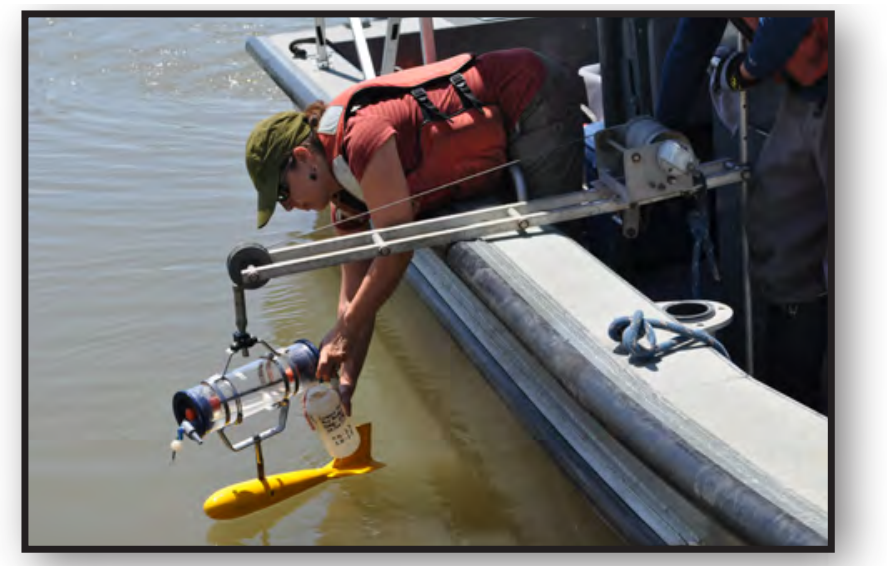

Figure 4. Scientist collecting a water sample by using a horizontally-positioned Van Dorn-style sampler with bridge board. 

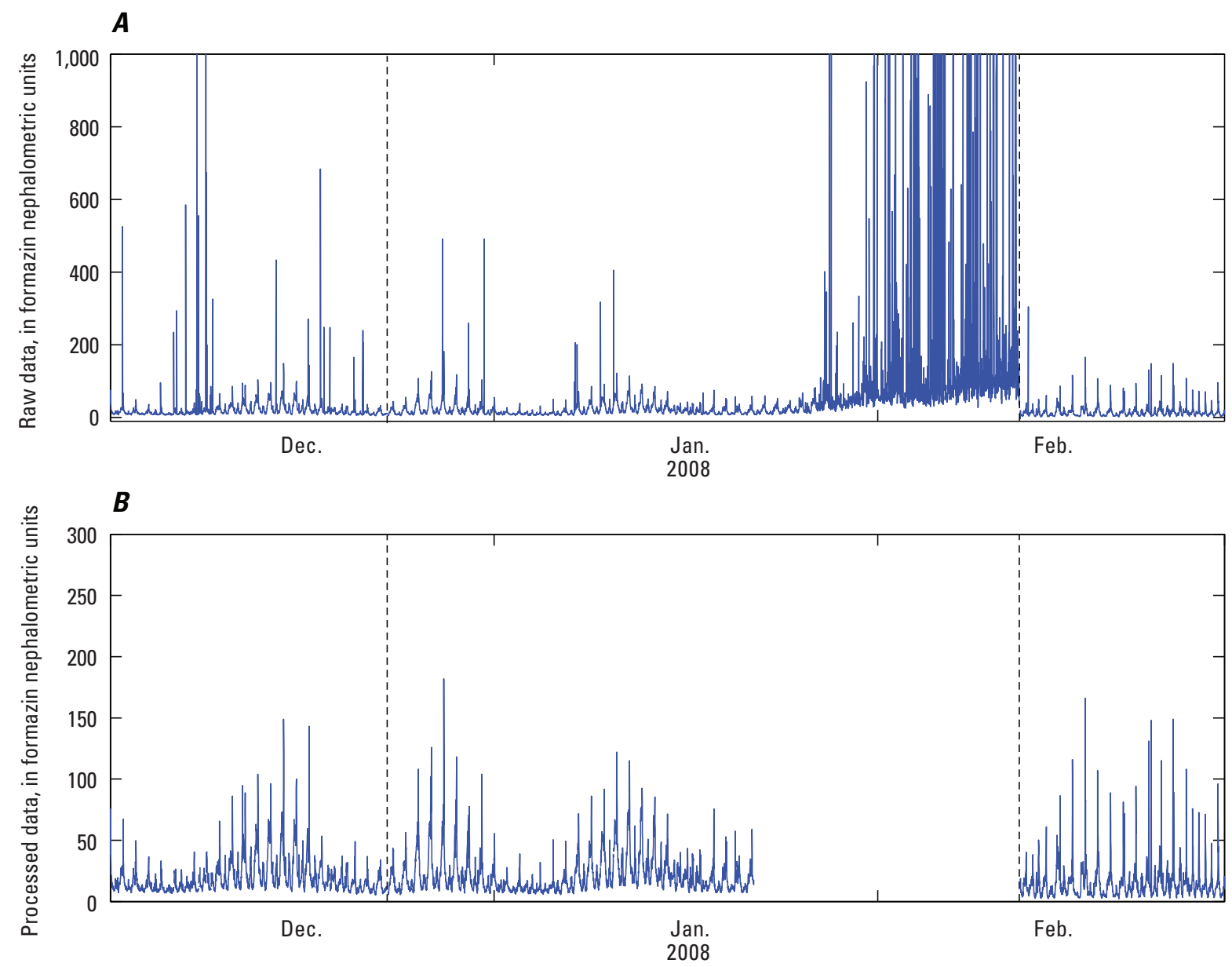

EXPLANATION

----- Cleaning

Figure 5. Example of optical sensor data, near-bottom sensor, Richmond/San Rafael Bridge, Central San Francisco Bay, California, water year 2009: $A$, raw and $B$, processed.

\section{Sensor Calibration and Suspended-Sediment Concentration Data}

The output from each of the two types of sensors used for this study is proportional to the SSC in the water column at the depth of the sensor. SSC calculated from the output of side-by-side sensors with different instrument designs were virtually identical (Buchanan and Schoellhamer, 1998). Calibration of the sensor output to SSC will vary according to the size and optical properties of the suspended sediment; therefore, the sensors must be calibrated by using suspended material from the field (Levesque and Schoellhamer, 1995).

The output from the optical sensors was used to calculate SSC by linear regression using the robust, nonparametric, repeated median method (Siegel, 1982). Ordinary least squares (OLS) regression was used to develop sensor calibration in cases where a nonparametric method was insufficient because of a poor distribution of data points (Helsel and Hirsch, 1992). Constant variance of residuals is a necessary condition for use of OLS regression to obtain the best linear unbiased estimator of a variable (Helsel and Hirsch, 1992, p. 225). The variance of the residuals for some datasets in this study increased with voltage and was not constant; therefore, robust regression was considered to be more appropriate than OLS regression for the development of calibration curves in most cases.

The nonparametric prediction interval and the 95-percent confidence interval were calculated and presented for each calibration equation. Whenever possible, water-sample data collected in previous water years were included in the calibrations to incorporate the largest range of observed concentrations. Previously collected water-sample data were discarded if a sensor's calibration had drifted. 
Robust statistics were used to estimate the slope of the equation for the nonparametric fit. The slope estimate was calculated from the comparison of all X, Y pairs. The repeated-median method calculated the calibration slope in a two-part process. First, for each point $(\mathrm{X}, \mathrm{Y})$ in a set of $n$ data points, the median of all possible "point $i$ " to "point $j$ " slopes was calculated:

$$
\beta_{i}=\operatorname{median} \frac{\left(Y_{j}-Y_{i}\right)}{\left(X_{j}-X_{i}\right)} \quad \text { for } j=1 \ldots n, \quad j \neq i
$$

The calibration slope was calculated as the median of $\mathrm{b} i$ :

$$
\text { slope }=\hat{\beta}_{1}=\text { median }\left(\beta_{i}\right) \text { for } i=1 \ldots n
$$

Finally, the calibration intercept was calculated as the median of all possible intercepts by using the slope calculated above:

$$
\text { intercept }=\hat{\beta}_{o}=\text { median }\left(Y_{i}-\hat{\beta}_{1} X_{i}\right) \quad \text { for } i=1 \ldots n
$$

The final linear calibration equation is:

$$
Y=\hat{\beta}_{1} X+\hat{\beta}_{o}
$$

The nonparametric prediction interval ( $P I_{\mathrm{np}}$; Helsel and Hirsch, 1992, p. 76 and 243) used for data analysis in this study, is a constant-width error band that contains about 68-percent, or one standard deviation, of the calibration data set. The 68-percent value was selected because it has about the same error prediction limits as the root-mean-squared (RMS) error of prediction that was used to describe the error associated with parametric OLS regression methods in previous data reports (Buchanan and Schoellhamer, 1995, 1996, 1998, 1999; Buchanan and others, 1996). The prediction interval describes the likelihood that a new observation comes from the same distribution as the previously collected data set.

The $P I_{\mathrm{np}}$, unlike the RMS error of prediction, frequently is not symmetrical about the regression line. For example, the $P I_{\mathrm{np}}$ could be reported as +10 and $-7 \mathrm{mg} / \mathrm{L}$. This asymmetry about the regression line is a result of the non-normal distribution of the data set. The $P I_{\text {np }}$ is calculated by computing and sorting, from least to greatest, the residuals for each point. Then, based on the sorted list of residuals:

$$
P I_{n p}=Y+e(L), \hat{Y}+e(U)
$$

where

$\hat{Y} \quad$ is the value of the predicted observation,

$\mathrm{e}(L)$ and $\mathrm{e}(U) \quad$ are the $\mathrm{L}^{\text {th }}$ and $\mathrm{U}^{\text {th }}$ ranked residuals, and

$$
L=(n+1) \times \frac{\alpha}{2} \quad \text { and } \quad U=(n+1) \times\left(1-\frac{\alpha}{2}\right)
$$

$n \quad$ is the number of data points, and

$\alpha$ is 0.32 for a 68 percent confidence.

To calculate the confidence interval for the regression line slope, all possible point-to-point slopes must be sorted in ascending order. The confidence interval (Helsel and Hirsh, 1992, p. 239) for the slope indicates the quality of the estimated slope. On the basis of the confidence interval desired, 95-percent for the purposes of this report, the ranks of the upper and lower intervals are calculated as follows:

$$
R_{u}=\frac{\frac{n(n-1)}{2}+1.96\left(\sqrt{\frac{n(n-1)(2 n+5)}{18}}\right)}{2}+1
$$


and

$$
R_{l}=\frac{\frac{n(n-1)}{2}-1.96\left(\sqrt{\frac{n(n-1)(2 n+5)}{18}}\right)}{2}
$$

where

$R_{u} \quad$ is the rank of the upper interval slope,

$R_{l} \quad$ is the rank of the lower interval slope, and

$n \quad$ is the number of samples.

To establish the 95-percent confidence interval on the slope of the equation, the calculated ranks are rounded to the nearest integer, and the slope associated with each rank in the sorted list is identified. Equations 6 and 7, which represent large-sample approximations for the ranks, were used for each of the confidence intervals presented in this report. For those sites that had 10 or fewer samples, however, an alternative and presumably slightly more accurate method, Kendall tau, described by Helsel and Hirsch (1992, p. 273-274), was used to calculate upper and lower bound ranks.

A statistical summary of the SSC calculated from optical sensor data is presented in table 2 . The usable percentage of a complete year of valid data (96 data points per day x 365 days) for each site also is presented in table 2.

This section of the report also includes figures showing graphical results of the regression analyses (calibration) relating SSC (in mg/L) to optical sensor output. The calibration figures (for example, fig. 6) include the number of water samples (points; all water samples used to develop calibration, including those from previous water years), the linear regression equation, the nonparametric prediction interval (shown on the calibration figures as a grey band), and the 95-percent confidence interval for the regression-line slope (table 3). In addition, the time-series plots of calculated SSC data are shown for each site.

Table 2. Statistical summary of calculated suspended-sediment concentration data and usable percentage of a complete year of valid data (96 data points per day x 365 days) collected by using optical sensors, Suisun Bay, San Pablo Bay, and Central and South San Francisco Bays, California, water year 2009.

[All values are in milligrams per liter except percentage of valid data. Lower quartile is $25^{\text {th }}$ percentile; upper quartile is $75^{\text {th }}$ percentile]

\begin{tabular}{|c|c|c|c|c|c|c|}
\hline Site & Depth & Mean & Median & $\begin{array}{c}\text { Lower } \\
\text { quartile }\end{array}$ & $\begin{array}{c}\text { Upper } \\
\text { quartile }\end{array}$ & $\begin{array}{l}\text { Valid data, } \\
\text { in percent }\end{array}$ \\
\hline Mallard Island & Near-surface & 24 & 23 & 18 & 30 & 97 \\
\hline Benicia Bridge & Near-surface & 34 & 29 & 23 & 40 & 86 \\
\hline Benicia Bridge & Near-bottom & 72 & 62 & 45 & 89 & 81 \\
\hline Richmond/San Rafael Bridge & Mid-depth & 28 & 20 & 14 & 33 & 85 \\
\hline Richmond/San Rafael Bridge & Near-bottom & 30 & 23 & 16 & 36 & 66 \\
\hline Alcatraz Island & Mid-depth & 18 & 16 & 13 & 20 & 62 \\
\hline Dumbarton Bridge & Mid-depth & 43 & 32 & 21 & 51 & 73 \\
\hline
\end{tabular}




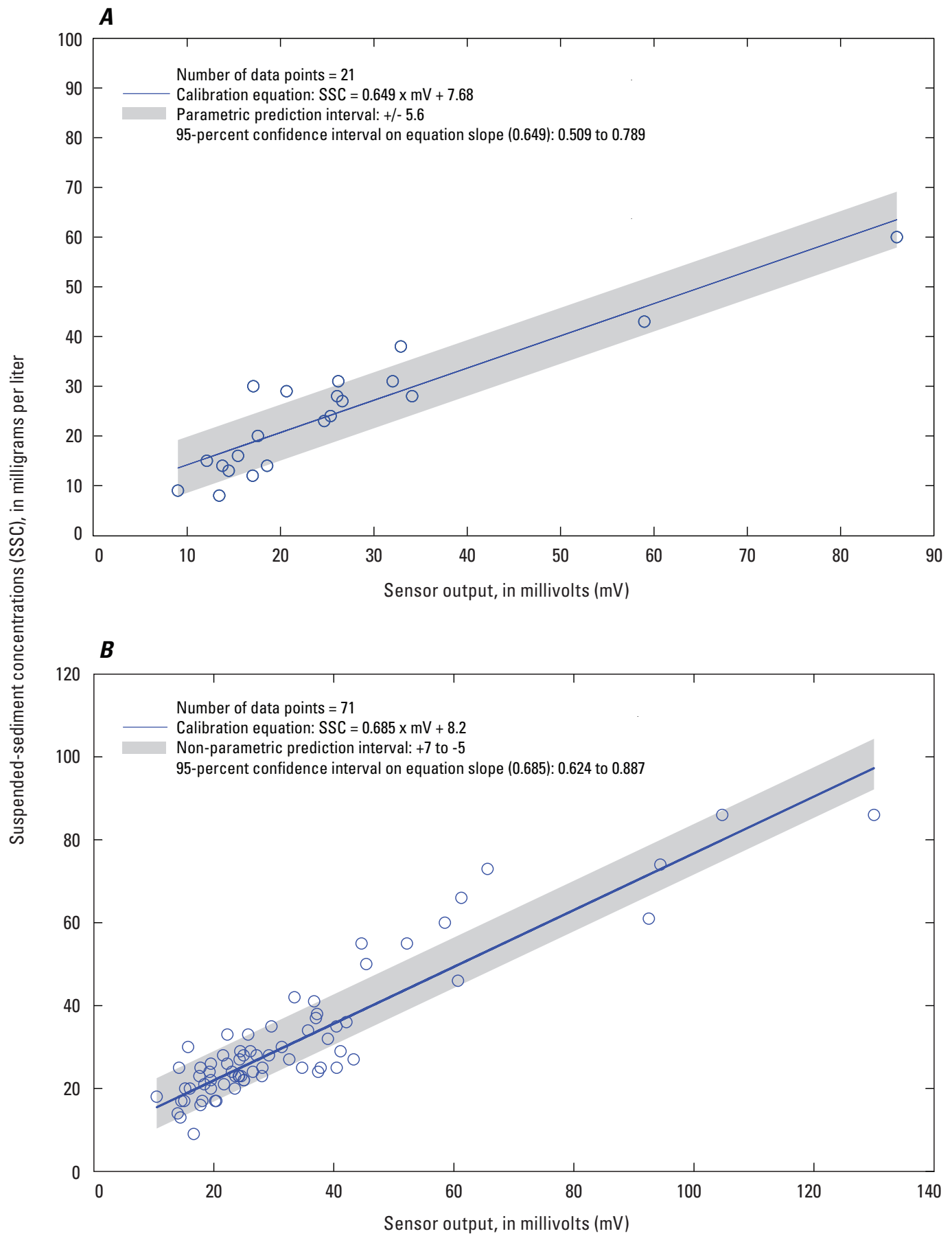

Figure 6. Calibration of optical sensors at Mallard Island, Suisun Bay, California, water year 2009: $A$, near surface and $B$, near bottom. 
Table 3. Summary of suspended-sediment concentration calibration statistics, Suisun Bay, San Pablo Bay, and Central and South San Francisco Bays, California, water year 2009.

[Period of calibration: 10/01/2008 to 09/30/2009. Abbreviations: FNU, formazin nephelometric units; mg/L, milligram per liter; mV, millivolt; SSC, suspendedsediment concentration; -, not applicable]

\begin{tabular}{|c|c|c|c|c|c|c|}
\hline Site & $\begin{array}{l}\text { Sensor } \\
\text { Iocation }\end{array}$ & $\begin{array}{l}\text { Number } \\
\text { of data } \\
\text { points } \\
\text { (water } \\
\text { samples) }\end{array}$ & $\begin{array}{l}\text { Linear } \\
\text { regression } \\
\text { equation }\end{array}$ & $\begin{array}{l}\text { Parametric } \\
\text { prediction } \\
\text { interval } \\
\text { (in } \mathrm{mg} / \mathrm{l} \text { ) }\end{array}$ & $\begin{array}{c}\text { Non-parametric } \\
\text { prediction } \\
\text { interval } \\
\text { (in mg/l) }\end{array}$ & $\begin{array}{l}\text { 95-percent } \\
\text { confidence } \\
\text { interval } \\
\text { on slope } \\
\text { calculation }\end{array}$ \\
\hline Mallard Island & Near-surface & 21 & $\mathrm{SSC}=0.649 \times \mathrm{mV}+7.68$ & +5.6 to -5.6 & - & 0.509 to 0.789 \\
\hline Mallard Island & Near-bottom & 71 & $\mathrm{SSC}=0.685 \times \mathrm{mV}+8.2$ & - & +7.0 to -5.0 & 0.624 to 0.887 \\
\hline Benicia Bridge & Near-bottom & 23 & $\mathrm{SSC}=1.29 \times \mathrm{FNU}+14.2$ & - & +16.0 to -16.0 & 1.09 to 1.51 \\
\hline Hamilton Disposal Site & Near-bottom & 7 & $\mathrm{SSC}=2.09 \times \mathrm{FNU}+3.0$ & - & +13.0 to -15.0 & 0.723 to 2.61 \\
\hline Richmond /San Rafael Bridge & Mid-depth & 43 & $\mathrm{SSC}=2.30 \times \mathrm{FNU}+4.6$ & - & +8.0 to -12.0 & 1.42 to 2.64 \\
\hline Richmond /San Rafael Bridge & Near-bottom & 44 & $\mathrm{SSC}=1.86 \times \mathrm{FNU}+5.4$ & +18.9 to -18.9 & - & 1.70 to 2.01 \\
\hline
\end{tabular}

\section{Mallard Island}

Interruptions in record were caused by fouling or malfunction of the sensing or recording instruments. Sensors were positioned at near-surface (attached to float assembly) and near-bottom depths to coincide with DWR near-surface and nearbottom sensors. The near-surface sensor malfunctioned and was replaced on August 26, 2009. A water sample from WY 2010 was included in the near-surface sensor calibration to supplement the number of water samples collected in WY 2009. The near-surface sensor calibration was developed by using OLS regression because of the poor distribution of data points (fig. 6A). The calculated SSC time-series data collected for WY 2009 are presented in figure 7. 


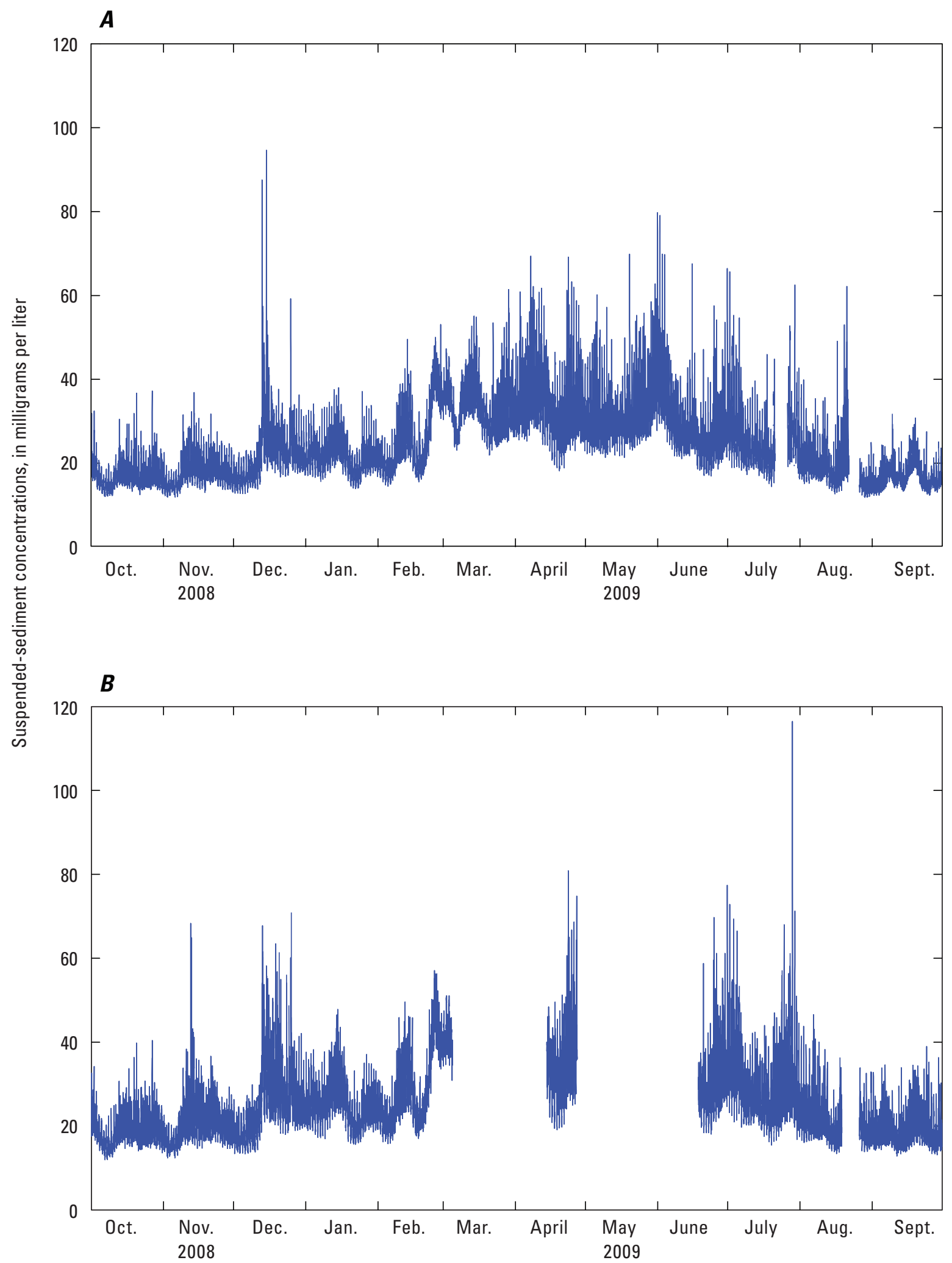

Figure 7. Time series of suspended-sediment concentrations calculated from sensor readings at Mallard Island, Suisun Bay, California, water year 2009: $A$, near surface and $B$, near bottom. 


\section{Benicia Bridge}

Interruptions in record were caused by fouling or malfunction of the sensing or recording instruments. Mean lower low water (MLLW) was approximately $80 \mathrm{ft}$ at the site but approximately $60 \mathrm{ft}$ immediately adjacent. Therefore, the nearbottom sonde was set approximately $20 \mathrm{ft}$ above the bottom so that the data were representative of the surrounding area. The near-surface sonde was replaced on June 03, 2009, because of a malfunctioning conductivity sensor. The near-surface sonde was replaced again on July 20, 2009; field notes indicated the optical sensor was not working, although data collected prior to the site visit were good. A calibration error during the site visit on February 10, 2009, necessitated the application of a +4.5 FNU shift to the near-surface record from February 10 through April 7, 2009. Calibration drift affected the near-surface sensor from July 20 to August 11, 2009, necessitating a shift proration from 0 FNU on July 20 to +3.6 FNU on August 11, 2009, when the optical sensor was calibrated. The near-surface sensor calibration was developed by using OLS regression because of the poor distribution of data points (fig. 8A). Because the two optical sensors (both YSI, Inc.'s) deployed at the near-surface position during WY 2009 responded similarly to the uniform sediment characteristics found in San Francisco Bay (Ganju and others, 2007), the calibration was developed by combining water samples collected during each sensor deployment. The near-bottom sonde was replaced on November 18, 2008, because of a flooded battery compartment. The optical sensor on the replacement sonde was not calibrated on deployment, necessitating a shift to the near-bottom time series record from November 18, 2008 to February 10, 2009, when the optical sensor was calibrated. Because the two optical sensors (both YSI, Inc.'s) deployed at the near-bottom position during WY 2009 responded similarly to the uniform sediment characteristics found in San Francisco Bay (Ganju and others, 2007), the calibration was developed by combining water samples collected during each sensor deployment. Water samples from WY 2010 were included in the near-bottom sensor calibration to supplement the number of water samples collected in WY 2009 (fig. 8B). The calculated SSC time-series data collected for WY 2009 are presented in figure 9. 

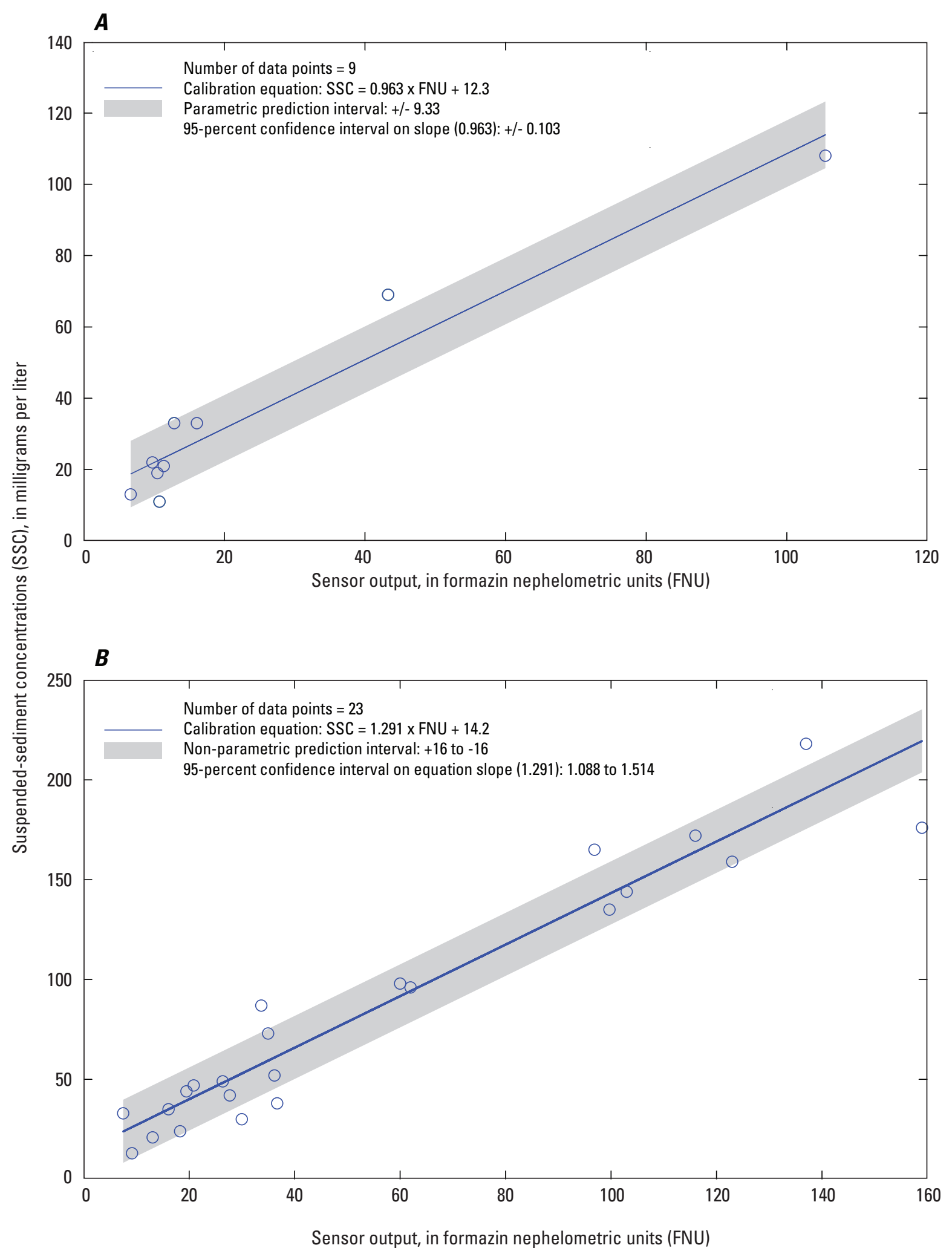

Figure 8. Calibration of optical sensors at Benicia Bridge, Suisun Bay, California, water year 2009: $A$, near surface and $B$, near bottom. 

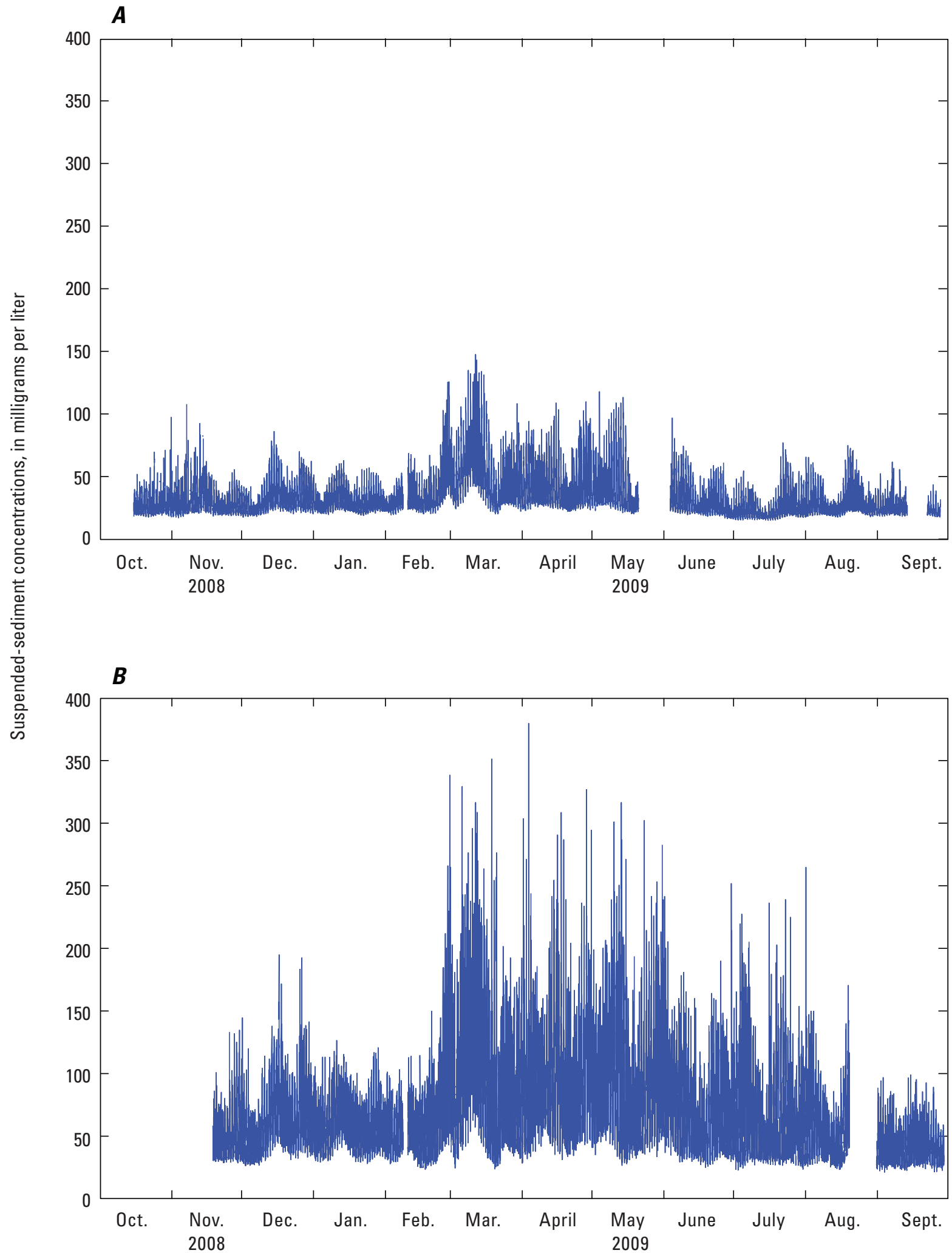

Figure 9. Time series of suspended-sediment concentrations calculated from sensor readings at Benicia Bridge, Suisun Bay, California, water year 2009: $A$, near surface and $B$, near bottom. 


\section{Hamilton Disposal Site}

Interruptions in record were caused by fouling, malfunction of the sensing or recording instruments, or loss of equipment. During periods of heavy fouling the optical sensor wiper was ineffective in keeping the optical ports clean because biological growth on the wiper obscured the optical ports. On August 12, 2009, the sub-surface buoy was found deflated, which caused the sonde to rest on the bottom resulting in unusable data from late June to August 12. On October 15, 2009, it was discovered that the sonde was not attached to the deployment cable and was never recovered. The calibration of optical sensors to SSC and calculated SSC time-series data collected for WY 2009 are presented in figures 10 and 11, respectively.

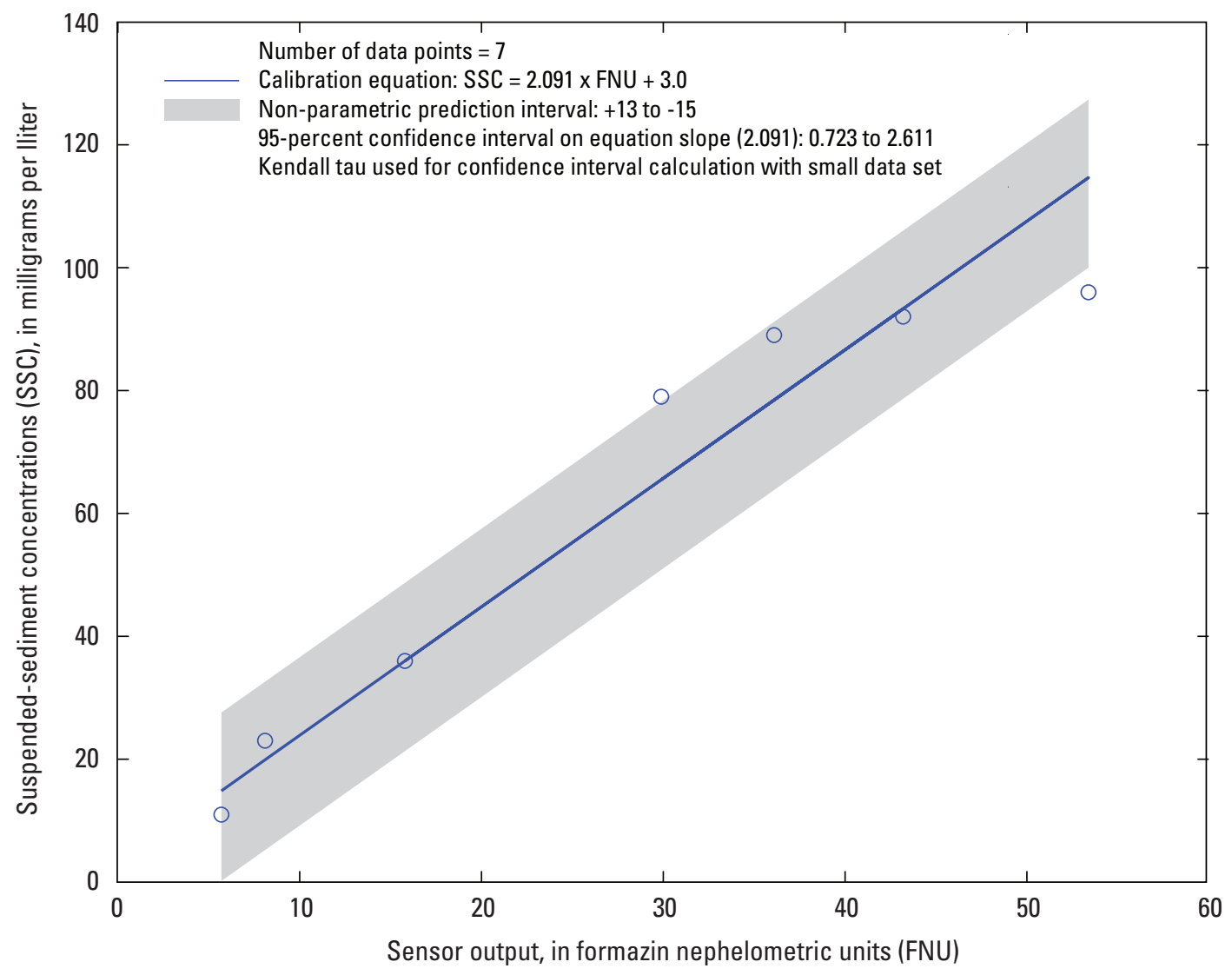

Figure 10. Calibration of near-bottom optical sensors at Hamilton Disposal Site, San Pablo Bay, California, water year 2009. 


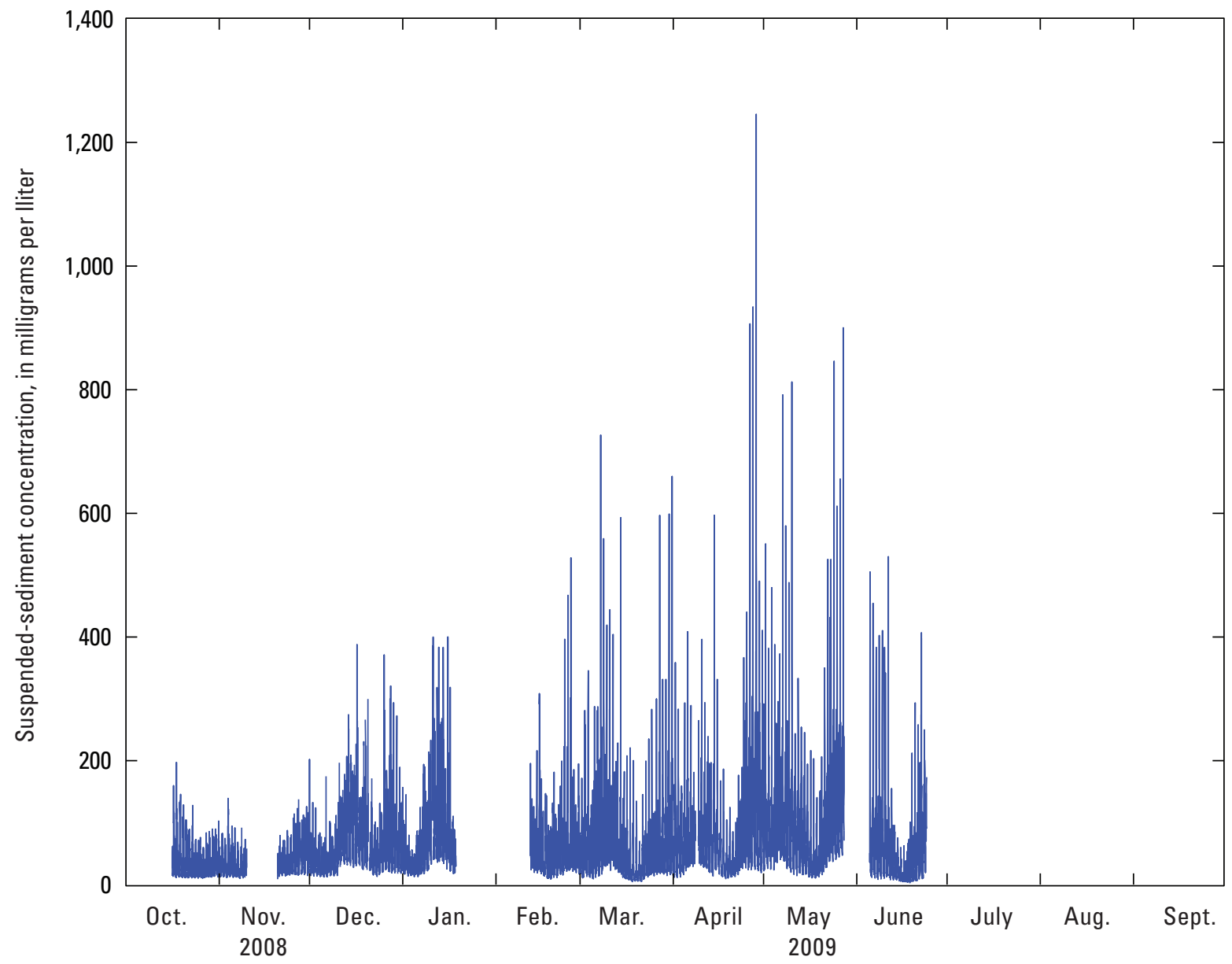

Figure 11. Time series of near-bottom suspended-sediment concentrations calculated from sensor readings at Hamilton Disposal Site, San Pablo Bay, California, water year 2009.

\section{Richmond/San Rafael Bridge}

Interruptions in record were caused by fouling or malfunction of the sensing or recording instruments. The optical sensors wipers were ineffective during periods of heavy fouling because biological growth on the wiper obscured the optical ports. The mid-depth turbidity sensor had low readings in zero turbidity standards, and a +4.1 NTU correction was applied to the time-series until February 12, 2009, when the sensor was calibrated. The near-bottom sonde malfunctioned and was replaced on March 07, 2009. Because the two optical sensors (both YSI, Inc.'s) deployed at the near- bottom position during WY 2009 responded similarly to the uniform sediment characteristics found in San Francisco Bay (Ganju and others, 2007), the calibration was developed by combining water samples collected during each sensor deployment. The near-bottom sensor calibration was developed by using OLS regression because of the poor distribution of data points (fig. 12B). The calculated SSC time-series data collected for WY 2009 are presented in figure 13. 

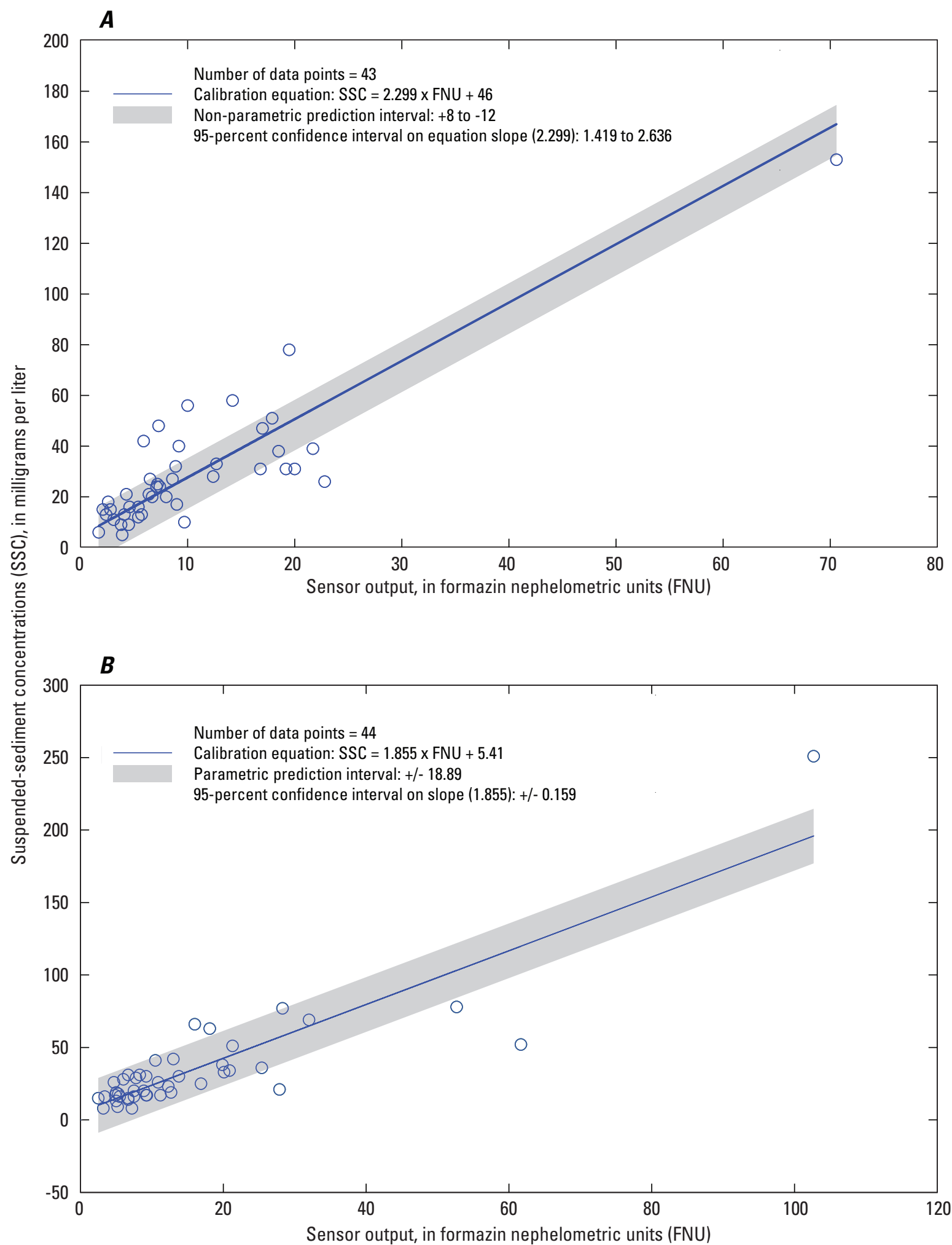

Figure 12. Calibration of optical sensors at Richmond/San Rafael Bridge, Central San Francisco Bay, California, water year 2009: $A$, mid-depth and $B$, near bottom. 


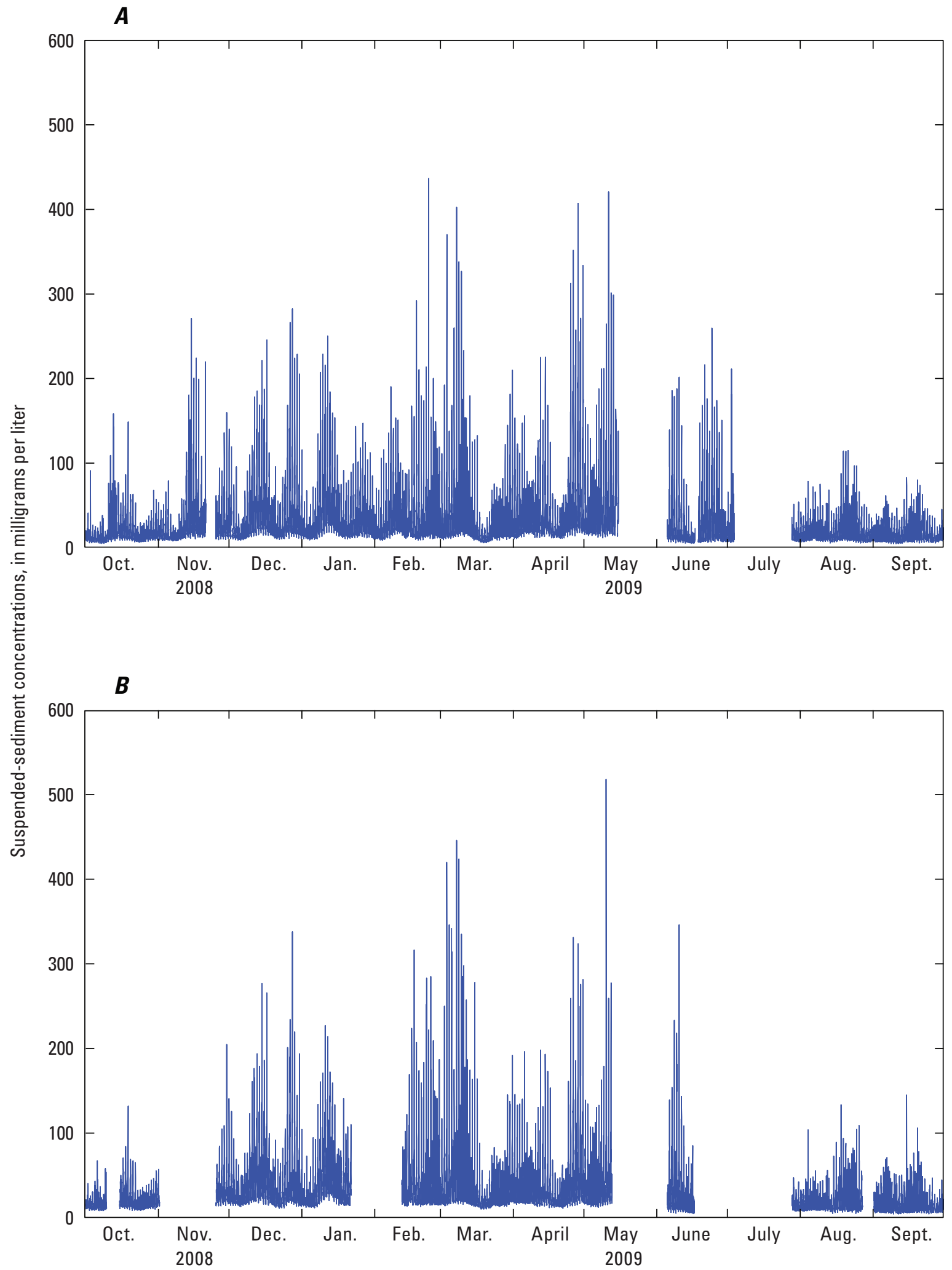

Figure 13. Time series of suspended-sediment concentrations calculated from sensor readings at Richmond/San Rafael Bridge, Central San Francisco Bay, California, water year 2009: $A$, mid-depth and $B$, near bottom. 


\section{Alcatraz Island}

Interruptions in record caused by fouling or malfunction of the sensing or recording instruments. The optical sensor wiper was ineffective during periods of heavy fouling because biological growth on the wiper obscured the optical ports. The sonde was replaced on October 23, 2008. Because the optical sensors (YSI, Inc.'s) deployed at the mid-depth position during WY 2009 responded similarly to the uniform sediment characteristics found in San Francisco Bay (Ganju and others, 2007), the calibration was developed by combining water samples collected during each sensor deployment (fig. 14). The calculated SSC time-series data collected for WY 2009 are presented in figure 15.

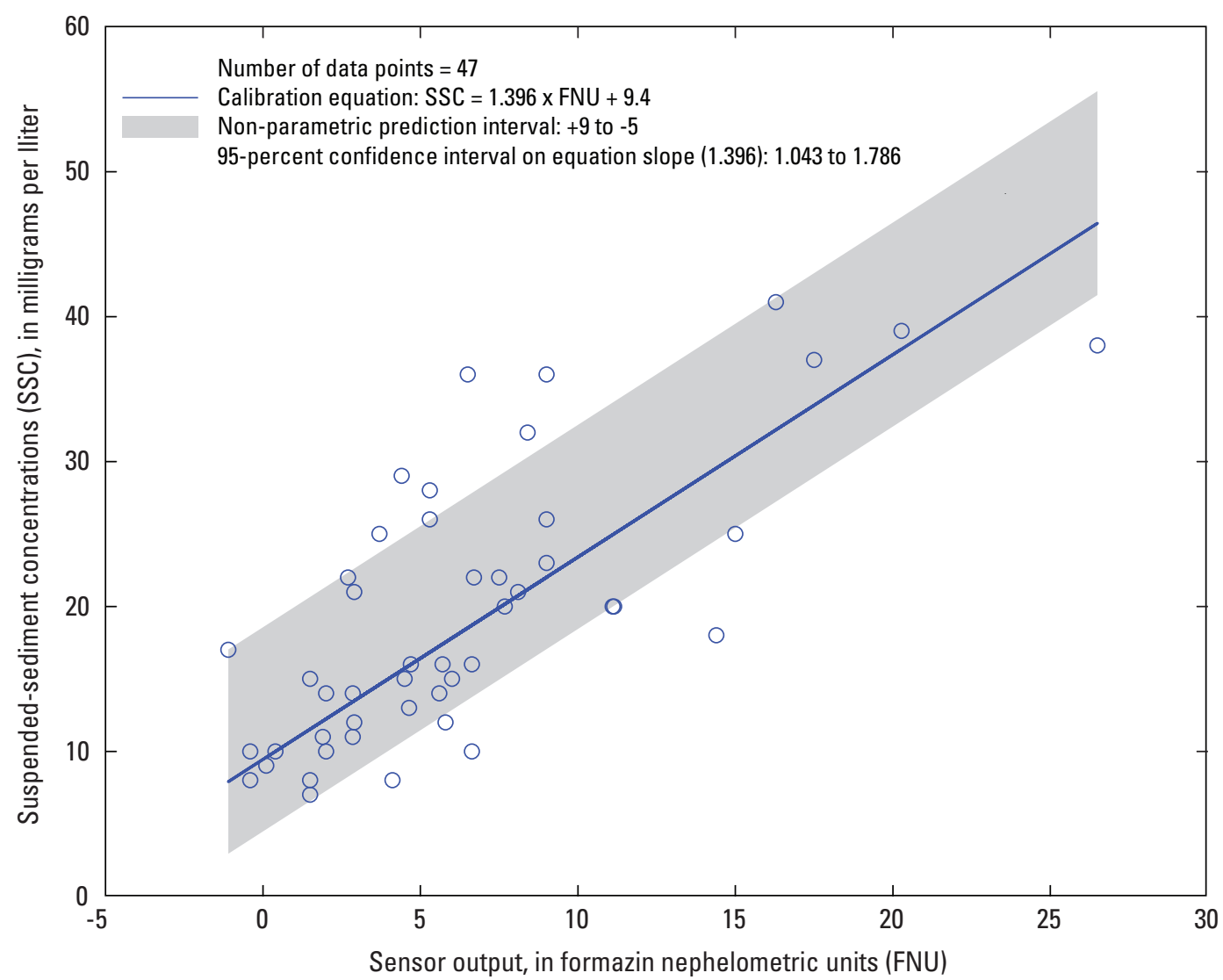

Figure 14. Calibration of mid-depth optical sensors at Alcatraz Island, Central San Francisco Bay, California, water year 2009. 


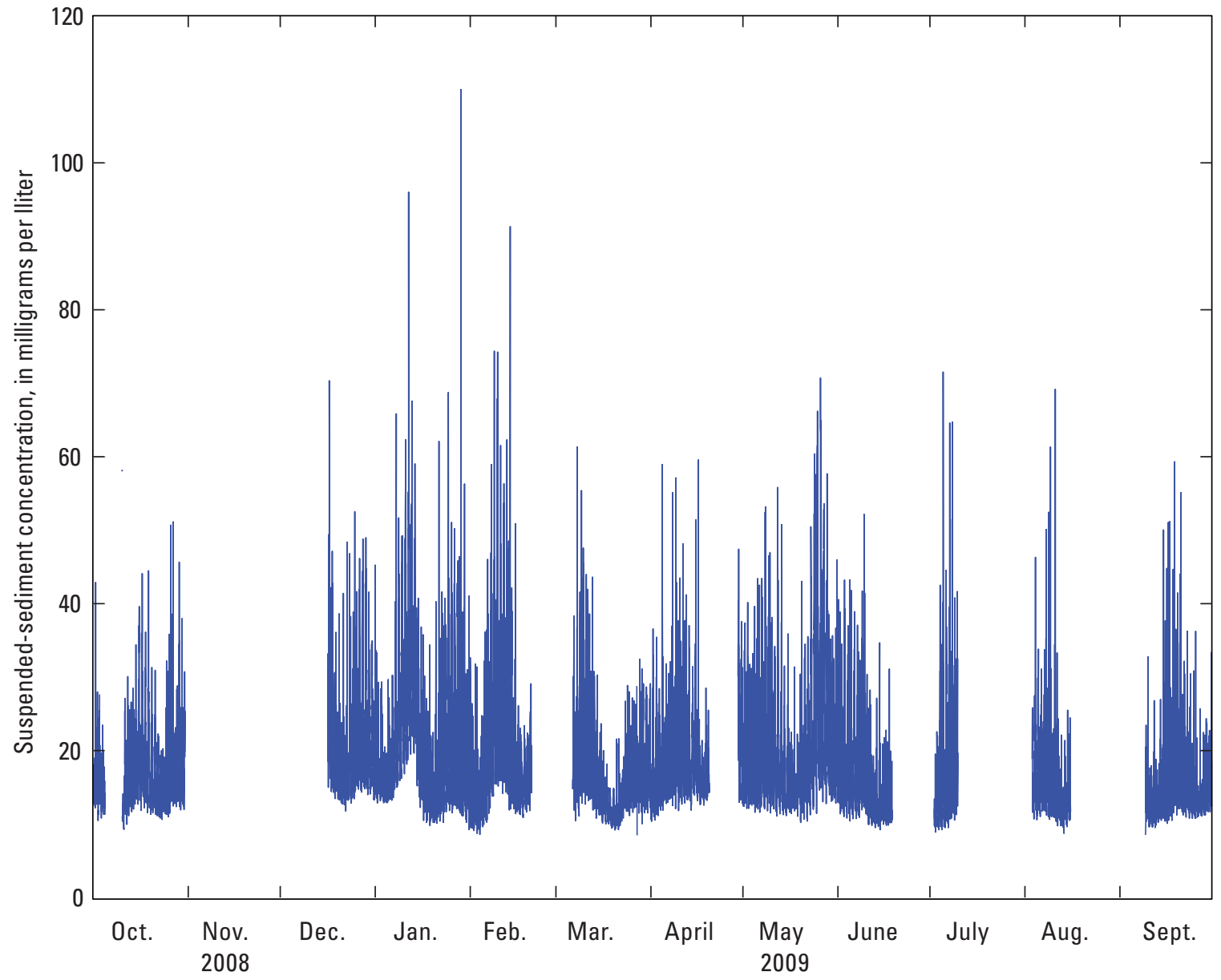

Figure 15. Time series of mid-depth suspended-sediment concentrations calculated from sensor readings at Alcatraz Island, Central San Francisco Bay, California, water year 2009. 


\section{Summary of Suspended-Sediment Concentration Data, San Francisco Bay, California, Water Year 2009}

\section{Dumbarton Bridge}

Interruptions in record were caused by fouling or malfunction of the sensing or recording instruments. The near-bottom optical sensor malfunctioned, and the sensor was replaced on January 15, 2009. Because the optical sensors (FTS-12's) deployed at the near-bottom position during WY 2009 responded similarly to the uniform sediment characteristics found in San Francisco Bay (Ganju and others, 2007), the calibration was developed by combining water samples collected during each sensor deployment (fig. 16). The calculated SSC time-series data collected for WY 2008 are presented in figure 17.

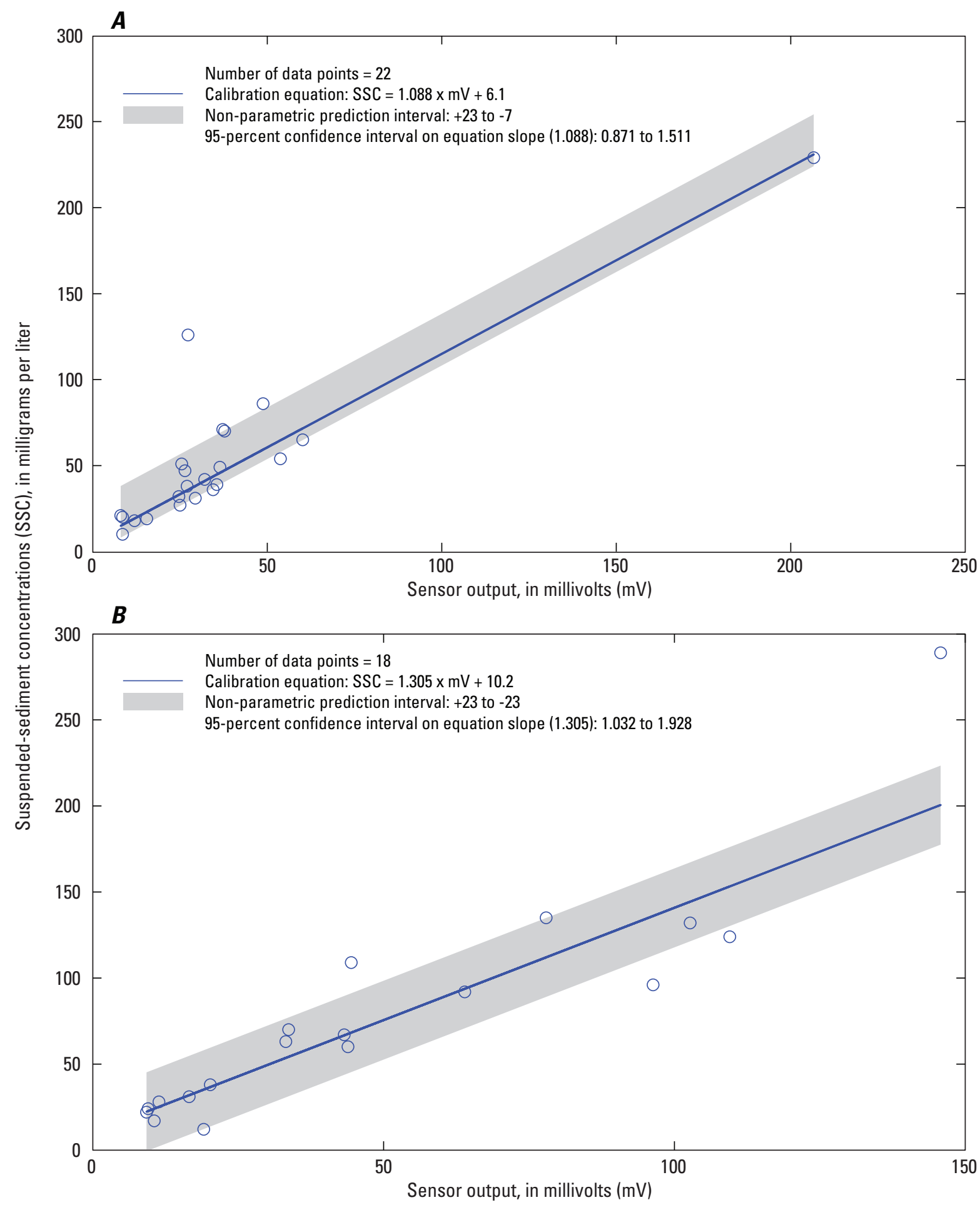

Figure 16. Calibration of optical sensors at Dumbarton Bridge, South San Francisco Bay, California, water year 2009: A, mid-depth and $B$, near bottom. 


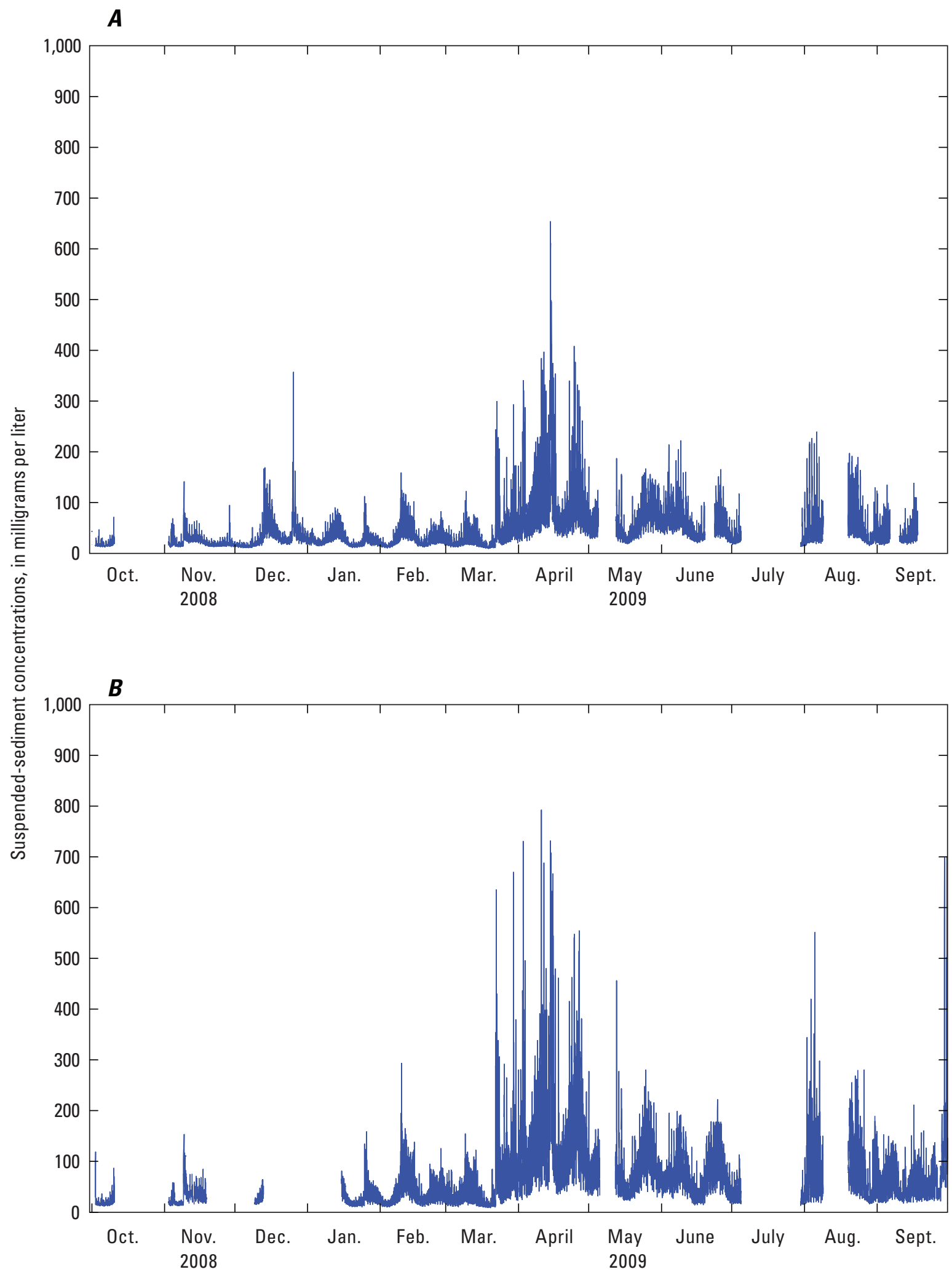

Figure 17. Time series of suspended-sediment concentrations calculated from sensor readings at Dumbarton Bridge, South San Francisco Bay, California, water year 2009: $A$, mid-depth and $B$, near bottom. 


\section{Summary}

Suspended-sediment concentration (SSC) data were collected by the U.S. Geological Survey (USGS) at two sites in Suisun Bay, two sites in Central San Francisco Bay, one site in San Pablo Bay and one site in South San Francisco Bay during water year 2009. Two types of optical sensors, each controlled by electronic data loggers, were used to monitor suspended sediment. Water samples were collected to calibrate the output of the optical sensors to SSC by using robust, nonparametric regression. Where nonparametric regression was not viable, parametric regression was used. Water-sample sediment-concentration data are available in the USGS Sediment Laboratory Environmental Database. Time-series data are available in the USGS sediment database and the USGS automated data-processing system database.

\section{References Cited}

Arthur, J.F., and Ball, M.D., 1979, Factors influencing the entrapment of suspended material in the San Francisco Bay-Delta Estuary, in Conomos, T.J., ed., San Francisco Bay: The urbanized estuary: San Francisco, Pacific Division of the American Association for the Advancement of Science, p. 143-174.

Brown, C.L., and Luoma, S.N., 1995, Use of the euryhaline bivalve Potamocorbula amurensis as a biosentinal species to assess trace metal contamination in San Francisco Bay: Marine Ecology Progress Series, v. 124, p. 129-142.

Buchanan, P.A., and Ganju, N.K., 2002, Summary of suspended-sediment concentration data, San Francisco Bay, California, water year 2000: U.S. Geological Survey Open-File Report 02-146, 42 p.

Buchanan, P.A., and Ganju, N.K., 2003, Summary of suspended-sediment concentration data, San Francisco Bay, California, water year 2001: U.S. Geological Survey Open-File Report 03-312, 47 p.

Buchanan, P.A., and Ganju, N.K., 2004, Summary of suspended-sediment concentration data, San Francisco Bay, California, water year 2002: U.S. Geological Survey Open-File Report 04-1219, 45 p.

Buchanan, P.A., and Ganju, N.K., 2005, Summary of suspended-sediment concentration data, San Francisco Bay, California, water year 2003: U.S. Geological Survey Data Series 113, 46 p.

Buchanan, P.A., and Lionberger, M.A., 2006, Summary of suspended-sediment concentration data, San Francisco Bay, California, water year 2004: U.S. Geological Survey Data Series 226, 49 p.

Buchanan, P.A., and Lionberger, M.A., 2007, Summary of suspended-sediment concentration data, San Francisco Bay, California, water year 2005: U.S. Geological Survey Data Series 282, 46 p.

Buchanan, P.A., and Lionberger, M.A., 2009, Summary of suspended-sediment concentration data, San Francisco Bay, California, water year 2006: U.S. Geological Survey Data Series 362, 35 p.

Buchanan, P.A., and Morgan, T.L., 2010, Summary of suspended-sediment concentration data, San Francisco Bay, California, Water Year 2007: U.S. Geological Survey Data Series 476, 30 p.

Buchanan, P.A., and Morgan, T.L., 2011, Summary of suspended-sediment concentration data, San Francisco Bay, California, water year 2008: U.S. Geological Survey Data Series 634, 34 p.

Buchanan, P.A., and Ruhl, C.A., 2000, Summary of suspended-solids concentration data, San Francisco Bay, California, water year 1998: U.S. Geological Survey Open-File Report 00-88, 41 p.

Buchanan, P.A., and Ruhl, C.A., 2001, Summary of suspended-sediment concentration data, San Francisco Bay, California, water year 1999: U.S. Geological Survey Open-File Report 01-100, 41 p.

Buchanan, P.A., and Schoellhamer, D.H., 1995, Summary of suspended-solids concentration data, Central and South San Francisco Bay, California, water years 1992 and 1993: U.S. Geological Survey Open-File Report 94-543, 15 p.

Buchanan, P.A., and Schoellhamer, D.H., 1996, Summary of suspended-solids concentration data, San Francisco Bay, California, water year 1995: U.S. Geological Survey Open-File Report 96-591, 40 p. 
Buchanan, P.A., and Schoellhamer, D.H., 1998, Summary of suspended-solids concentration data, San Francisco Bay, California, water year 1996: U.S. Geological Survey Open-File Report 98-175, 59 p.

Buchanan, P.A., and Schoellhamer, D.H., 1999, Summary of suspended-solids concentration data, San Francisco Bay, California, water year 1997: U.S. Geological Survey Open-File Report 99-189, 52 p.

Buchanan, P.A., Schoellhamer, D.H., and Sheipline, R.C., 1996, Summary of suspended-solids concentration data, San Francisco Bay, California, water year 1994: U.S. Geological Survey Open-File Report 95-776, 48 p.

Carlson, P.R., and McCulloch, D.S., 1974, Aerial observations of suspended-sediment plumes in San Francisco Bay and adjacent Pacific Ocean: U.S. Geological Survey Water-Resources Research, v. 2, no. 5, p. 519-526.

Cheng, R.T., and Gartner, J.W., 1984, Tides, tidal and residual currents in San Francisco Bay, California—Results of measurements, 1979-1980: U.S. Geological Survey Water-Resources Investigations Report 84-4339, 72 p.

Cloern, J.E., 1987, Turbidity as a control on phytoplankton biomass and productivity in estuaries: Continental Shelf Research, v. 7 , no. $11 / 12$, p. $1367-1381$.

Cloern, J.E., 1996, Phytoplankton bloom dynamics in coastal ecosystems: a review with some general lessons from sustained investigation of San Francisco Bay, California: Reviews of Geophysics, v. 34, no. 2, p. 127-168.

Cole, B.E., and Cloern, J.E., 1987, An empirical model for estimating phytoplankton productivity in estuaries: Marine Ecology Progress Series, v. 36, p. 299-305.

Conomos, T.J., and Peterson, D.H., 1977, Suspended-particle transport and circulation in San Francisco Bay, an overview: New York, Academic Press, Estuarine Processes, v. 2, p. 82-97.

Domagalski, J.L., and Kuivila, K.M., 1993, Distributions of pesticides and organic contaminants between water and suspended sediment, San Francisco Bay, California: Estuaries, v. 16, no. 3A, p. 416-426.

Fishman, M.J., and Friedman, L.C., 1989, Methods for determination of inorganic substances in water and fluvial sediments: U.S. Geological Survey Techniques of Water-Resources Investigations, book 5, chap. A1, 545 p.

Flegal, A.R.; Rivera-Duarte, Ignacio; Ritson, P.I.; Scelfo, G.M.; Smith, G.J.; Gordon, M.R.; and Sanudo-Wilhelmy, S.A., 1996, Metal contamination in San Francisco Bay waters: Historic perturbations, contemporary concentrations, and future considerations: San Francisco Bay: The Ecosystem, Hollibaugh, J.T., ed., Pacific Division of the American Association for the Advancement of Science, San Francisco, p. 173-188.

Ganju, N.K., Schoellhamer, D.H., Murrell, M.C., Gartner, J.W., and Wright, S.A., 2007, Constancy of the relation between floc size and density in San Francisco Bay, in Maa, J.P.-Y., Sanford, L.P., and Schoellhamer, D.H., eds., Estuarine and Coastal Fine Sediments Dynamics: Elsevier Science, p. 75-91.

Gray, J.R., Glysson, G.D., Turcios, L.M., and Schwarz, G.E., 2000, Comparability of suspended-sediment concentration and total suspended-solids data: U.S. Geological Survey Water-Resources Investigations Report 00-4191, 14 p.

Greenberg, A.E., Clesceri, L.S., and Eaton, A.D., 1992, Standard methods for the examination of water and wastewater: American Public Health Association, $18^{\text {th }}$ ed., variously paged.

Hammond, D.E.; Fuller, Christopher; Harmon, Dana; Hartman, Blayne; Korosec, Michael; Miller, L.G.; Rea, Rebecca; Warren, Steven; Berelson, William; and Hager, S.W., 1985, Benthic fluxes in San Francisco Bay: Hydrobiologia, v. 129, no. 1, p. 69-90.

Helsel, D.R., and Hirsch, R.M., 1992, Statistical methods in water resources: Studies in Environmental Science, v. 49, 522 p.

Jassby, A.D., and Powell, T.M., 1994, Hydrodynamic influences on interannual chlorophyll variability in an estuary: Upper San Francisco Bay-Delta (California, U.S.A.): Estuarine, Coastal and Shelf Science, v. 39, p. 595-618.

Kimmerer, Wim, 1992, An evaluation of existing data in the entrapment zone of the San Francisco Bay Estuary: Tiburon, Calif., Biosystems Analysis, Inc., Technical Report 33, 49 p.

Kuwabara, J.S., Chang, C.C.Y., Cloern, J.E., Fries, T.L., Davis, J.A., and Luoma, S.N., 1989, Trace metal associations in the water column of South San Francisco Bay, California: Estuarine, Coastal and Shelf Science, v. 28, p. 307-325. 
Levesque, V.A., and Schoellhamer, D.H., 1995, Summary of sediment resuspension monitoring, Old Tampa Bay and Hillsborough Bay, Florida, 1988-91: U.S. Geological Survey Water-Resources Investigations Report 94-4081, 31 p.

Lewicki, Mikolaj, and McKee, Lester, 2009, Watershed specific and regional scale suspended sediment loads for Bay Area small tributaries: A technical report for the Sources Pathways and Loading Workgroup of the Regional Monitoring Program for Water Quality: Oakland, Calif., San Francisco Estuary Institute: SFEI Contribution No. 566, 56 p.

Luoma, S.N., 1996, The developing framework of marine ecotoxicology: Pollutants as a variable in marine ecosystems?: Journal of experimental marine biology and ecology, v. 200, p. 29-55.

Luoma, S.N., Cain, Daniel, and Johansson, Christopher, 1985, Temporal fluctuations of silver, copper, and zinc in the bivalve Macoma balthica at five stations in South San Francisco Bay: Hydrobiologia, v. 129, p. 109-120.

Peterson, D.H., Conomos, T.J., Broenkow, W.W., and Doherty, P.C., 1975, Location of the non-tidal current null zone in northern San Francisco Bay: Estuarine and Coastal Marine Science, v. 3, p. 1-11.

Powell, T.M., Cloern, J.E., and Huzzey, L.M., 1989, Spatial and temporal variability in South San Francisco Bay (U.S.A.). I. Horizontal distributions of salinity, suspended sediments, and phytoplankton biomass and productivity: Estuarine, Coastal and Shelf Science, v. 28, p. 583-597.

Schoellhamer, D.H., 1996, Factors affecting suspended-sediment concentrations in South San Francisco Bay, California: Journal of Geophysical Research, v. 101, no. C5, p. 12087-12095.

Schoellhamer, D.H., 2001, Influence of salinity, bottom topography, and tides on locations of estuarine turbidity maxima in northern San Francisco Bay, in McAnally, W.H., and Mehta, A.J., eds., Coastal and Estuarine Fine Sediment Transport Processes: Elsevier Science, p. 343-357, available online at URL http://ca.water.usgs.gov/abstract/sfbay/elsevier0102.pdf

Schoellhamer, D.H., and Burau, J.R., 1998, Summary of findings about circulation and the estuarine turbidity maximum in Suisun Bay, California: U.S. Geological Survey Fact Sheet FS-047-98, 6 p.

Schoellhamer, D.H., Mumley, T.E., and Leatherbarrow, J.E., 2007, Suspended sediment and sediment-associated contaminants in San Francisco Bay: Environmental Research, v. 105, p. 119-131.

Siegel, A.R., 1982, Robust regression using repeated medians: Biometrika, v. 69, p. 242-244.

Smith, L.H., 1987, A review of circulation and mixing studies of San Francisco Bay, California: U.S. Geological Survey Circular $1015,38 \mathrm{p}$.

U.S. Environmental Protection Agency, 1992, Chapter 8. State of the estuary: Dredging and waterway modification: U.S. Environmental Protection Agency San Francisco Estuary Project, p. 191-215.

U.S. Geological Survey, 2004, Revision of NFM Chapter 6, Section 6.7-Turbidity: Office of Water Quality Technical Memorandum 2004.03, available online at URL http://water.usgs.gov/admin/memo/QW/qw04.03.html

U.S. Geological Survey, variously dated, USGS Publications related to continuous monitoring of San Francisco Bay: accessed December 2, 2008, at URL http://ca.water.usgs.gov/mud/publications.html

U.S. Geological Survey, variously dated, Publications of the San Francisco Bay sediment group: accessed March 3, 2011, at URL http://ca.water.usgs.gov/mud/publications.html

U.S. Geological Survey, variously dated, Continuous monitoring in the San Francisco Bay and Delta: accessed December 2, 2008, at URL http://sfbay.wr.usgs.gov/sediment/cont_monitoring/index.html

Wagner, R.J., Boulger, R.W., Jr., Oblinger, C.J., and Smith, B.A., 2006, Guidelines and standard procedures for continuous water-quality monitors - Station operation, record computation, and data reporting: U.S. Geological Survey Techniques and Methods 1-D3, 51 p., 8 attachments, accessed April 10, 2006, at URL http://pubs.water.usgs.gov/tm1d3 
Prepared by the Sacramento Publishing Service Center.

For more information concerning this report, contact:

Director

U.S. Geological Survey

California Water Science Center

6000 J Street, Placer Hall

Sacramento, CA 95819

GS-W-CAWSC_WWW@usgs.gov

or visit our Web site at:

http://ca.water.usgs.gov 


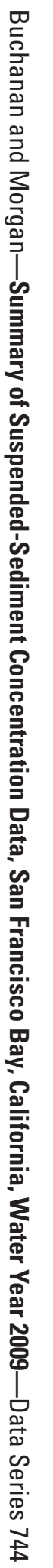

8 Printed on recycled paper 